\title{
Polychaete diversity patterns on two Arctic shelves: impacts of ice and primary production?
}

\author{
WILLIAM G. AMBROSE, JR. ${ }^{1,2,4}$, PAUL E. RENAUD ${ }^{1}$, SABINE K.J. COCHRANE ${ }^{1}$, STANISLAV \\ G. DENISENKO ${ }^{3}$ \& JOFRID SKARĐHAMAR ${ }^{1}$ \\ ${ }^{1}$ Akvaplan-niva, Polar Environmental Centre, N9296, Troms $\phi$, Norway \\ ${ }^{2}$ Department of Biology, Bates College, Lewiston, Maine 04230, USA \\ ${ }^{3}$ Zoological Institute, Russian Academy of Sciences, Universitetskaya nab. 1, St. Petersburg, 199034, Russia \\ ${ }^{4}$ Corresponding author. E-mail: wambrose@bates.edu
}

\begin{abstract}
We used data sets from two Arctic shelves to examine relationships between primary production (or a proxy), ice cover, and the diversity of polychaetes. Benthic samples were collected from the Northeast Water Polynya on the Northeast Greenland shelf and from the Barents Sea. Each of these areas is characterized by large differences in seasonal ice cover and primary production on a mesoscale. In addition to enumerating polychaete diversity, we also quantified the concentration of benthic algal pigments, sediment percent organic carbon, ice cover for the four years preceding sampling, and sediment grain size. In the Barents Sea, primary production was estimated from an ecosystem model. In both northeast Greenland and the Barents Sea, locations with lower primary production (Barents Sea) or proxies for primary production (benthic algal pigments: Greenland and Barents Sea), exhibited the greatest taxonomic richness. In Greenland, the area with the lowest concentration of benthic pigments had an $\mathrm{ES}_{(201)}$ up to $30 \%$ higher than values from areas with four times more pigments. In the Barents Sea, $\mathrm{ES}_{(201)}$ was greatest in the North under heaviest ice cover (>25\% cover per year), again approximately $30 \%$ higher than in the South ( $<15 \%$ cover) or under the Polar Front (15-25\% cover). Other factors also explained diversity: multiple regressions and Principal Component Analysis indicated that grain size, water depth and concentration of sediment organic carbon were important predictors of species diversity (Shannon-Wiener Index and Simpson's Reciprocal Index), but the results of these analyses were occasionally different from the patterns observed in the species accumulation curves or $\mathrm{ES}_{(201)}$ values. Simpson's Index indicated that high ice-cover (and low primary production and benthic pigment) areas in the Barents Sea had greater evenness (lower dominance) than regions with higher indicators of food supply to the benthos. Low resource levels may prevent a few species from becoming very abundant and outcompeting rare species. Diversity indices from northeast Greenland did not vary significantly among regions. We did not address habitat heterogeneity, but patchy distribution of food, combined with small- scale sediment heterogeneity also could enhance richness in food-poor areas. While the mechanism for the relationship between polychaete species richness and ice concentration or primary production is not clear, it does suggest that a change in polychaete diversity may need to be added to the list of possible responses of the benthos to climate-driven changes in ice cover.
\end{abstract}

Key words: Arctic, productivity, ice cover, Northeast Water Polynya, Barents Sea

\section{Introduction}

Ecologists have long been interested in the relationship between species diversity and primary 
production (Rosenzweig \& Abramsky 1993; Waide et al. 1999; Mittelbach et al. 2001; Gillman \& Wright 2006). Despite numerous studies spawned by a renewed interest in this relationship, there is considerable controversy over the nature of the production-diversity relationship (Schmid 2002). Claims have been made that this relationship is unimodal, with the highest diversity at intermediate levels of production (Rosenweig 1995), or linearly related, either positively (Gillman \& Wright 2006) or negatively (Haddad et al. 2000). What appears more likely is that the form of the relationship is dependent on the taxonomic groups examined, scale (Waide et al. 1999; Mittelbach et al. 2001), history (Fukami \& Morin 2003), level of disturbance (Kondoh 2001; Svensson et al. 2007), and the metric used to measure primary production (Thackeray 2007). In aquatic systems, the relationship does appear to be predominantly, though not exclusively, unimodal (Mittelbach et al. 2001). Many of the aquatic studies showing a unimodal relationship have examined primary production and invertebrate diversity, especially zooplankton in lacustrine systems (Dodson 1992, Dodson et al. 2000; Declerck et al. 2007).

A unimodal relationship between production and diversity is proposed for many systems because intermediate levels of production are hypothesized to favor the highest number of taxa. At low levels of production, only a few taxa can survive the limits set by low resources. As production increases, populations are larger and rarer species less prone to extinction (Huston 1994; Declerck et al. 2007). There is no consensus for the explanations of lower diversity at high production levels (Rosenweig 1995): heterogeneity of resources may be reduced (Tilman 1982), competitive displacement may be more common (Huston 1994), and/or predation may be more intense than at lower levels (Steiner 2003). Under extreme eutrophic conditions, many aquatic species are excluded due to hypoxic or anoxic conditions on the seafloor (Pearson \& Rosenberg 1978).

Tests of the productivity-diversity hypothesis involve both sampling across gradients in productivity (Rex et al. 2005) and manipulative experiments (Declerck et al. 2007). In marine systems, tests have involved sampling across the gradient of declining production accompanying an increase in water depth moving from the shelf to bathyal depths (Levin \& Gage 1998; Rex et al. 2005). The one study explicitly examining the relationship between benthic diversity and primary production in the deep sea did not find a unimodal relationship and only a suggestion of increasing diversity with productivity (Glover et al. 2002). Few marine studies have examined changes in diversity across gradients on continental shelves (Brandt 1997; Starmans et al. 1999; Ellingsen 2001, 2002).

Arctic shelves offer an ideal system in which to test the productivity-diversity relationship for benthic communities for two reasons. First, annual phytoplankton production in the Arctic is directly proportional to the temporal extent of open water (Rysgaard et al. 1999), and ice cover is often variable on a mesoscale. Second, because of tight pelagic-benthic coupling, benthic biomass and community composition on Arctic shelves are, in part, a reflection of ice cover, with highest biomass associated with more ice free areas (Grebmeier et al. 1988; Ambrose \& Renaud 1995; Piepenburg et al. 1997). Documented reductions in the thickness (Mclaren et al. 1992; Rothrock et al. 1999; Laxon et al. 2003) and aerial extent of sea ice (Johannessen et al. 1999, 2002; Serreze et al. 2003), and an increase in the number of ice-free days in seasonally ice-covered areas (Parkinson et al. 1999; Clarke \& Harris 2003), all presumably in response to warming, have been postulated to have profound effects on the structure and function of the Arctic marine ecosystem (Gradinger 1995; Carroll \& Carroll 2003; Renaud et al. 2008b). The effects of ice cover on the species diversity of benthic communities have received little attention.

We used two data sets to examine the relationships between primary productivity (or its proxy), ice cover, and the diversity of polychaetes. We chose polychaetes because they are numerical dominants in most Arctic soft-sediment shelf systems (Kendall et al. 2003), as well as world-wide 
(Fauchald 1977). Further, polychaete assemblages are considered useful as environmental indicators (Giangrande et al. 2005). On the northeast Greenland shelf we sampled the area encompassed by the Northeast Water polynya, which offered the chance to sample areas of different ice cover, but otherwise generally similar depth and sediment type. The second data set was collected in the Barents Sea from the nearly ice-free Atlantic Water areas in the south, to heavily ice covered stations in Arctic Water to the north. In both areas we ask if the diversity of polychaetes varies with different ice cover and differences in water column production or a proxy for productivity, benthic pigment concentration, which may be more relevant for benthic organisms than phytoplankton production.

\section{Materials and methods}

Site descriptions. The Northeast Water Polynya (NEW) is a summer polynya off the northeast coast of Greenland (Parkinson et al. 1987). The NEW polynya varies in size among years, but lies between $77^{\circ}$ and $81^{\circ} \mathrm{N}$ latitude and $5^{\circ}$ and $15^{\circ} \mathrm{W}$ longitude and is bounded by the coast of Greenland on the west and the south-flowing East Greenland Current on the east. The polynya opens in the northwest corner in April or May and closes in September (Minnett et al. 1997). In some years, southern and eastern areas may experience no open water. The polynya is often centered over two shallow Banks, $\mathrm{Ob}$ and Belgica Banks. The larger of these two, Belgica Bank, is bounded on the north, south, and west by troughs with an average depth of $300 \mathrm{~m}$ and some depths exceeding $500 \mathrm{~m}$. Fine sediments predominate in the trenches whereas coarse sediments characterize the banks, except in deeper depressions (Ambrose \& Renaud 1995). For a more detailed description of the bathymetry and water circulation see Bourke et al. (1987) and Schneider \& Budéus (1994).

The Barents Sea is a marginal sea located on the northern European continental shelf and open to the central Arctic basin to the northeast and the Norwegian and Greenland Seas to the west and covering $1.6 \times 10^{6} \mathrm{~km}^{2}$ (Carmack et al. 2006). It is bounded by land on the south (continental land of Norway and Russia), east (Novaya Semlya), and north by the Svalbard and Franz-Josef Land archipelagos. The western boundary of the sea is considered to be a line between South Cape (West Spitzbergen) to North Cape (Norway) passing through Bear Island.

The bathymetry of the Barents Sea is complex. While the average depth of the sea is about 200 $\mathrm{m}$, it is characterized by shallow (less than $50 \mathrm{~m}$ deep) banks and deeper (greater than $300 \mathrm{~m}$ ) trenches (Wassmann et al. 2006a). The variability in depth is matched by variability in sediment grain size. In general, the deeper areas tend to be dominated by muds and fine sands, with an admixture of gravel in shallower areas, especially on the banks (Fredriksen et al. 1994).

The Polar Front is a well-known feature in the central Barents Sea (Loeng 1991; Wassmann et al. 2006a), and is the zone where relatively warm and saline Atlantic $\left(>0^{\circ} \mathrm{C},>34.8 \mathrm{psu}\right)$ and cold, less saline Arctic $\left(<0^{\circ} \mathrm{C},<34.8 \mathrm{psu}\right)$ water masses meet. The convergence of these two different water masses results in enriched pelagic and benthic communities (Denisenko 2002; Carroll et al. 2008), presumably due to higher vertical flux of fresh material to the sea floor (Carmack \& Wassmann 2006).

Sampling. Samples from NEW were collected between June and August from the USCG vessel Polar Sea and the R/V Polarstern in 1992 (15 stations) and 1993 (13 stations) using a 0.25- ${ }^{2}$ USNEL Mark III box core (Fig. 1; Ambrose \& Renaud 1995; Piepenburg et al. 1997). Macrofauna were subsampled from box cores with 8 -cm-diameter x $15-\mathrm{cm}$-deep cores. Three to five replicates were taken from each box core and the contents sieved on a 500- $\mu \mathrm{m}$-mesh sieve. Material retained on the sieve was fixed in $10 \%$ formalin, stained with Rose Bengal, and eventually sorted using a dissecting microscope at $25 \mathrm{X}$ magnification. 
Samples from the Barents Sea (BASICC) were collected in August 2003 from the RV Ivan Petrov using a modified $0.1-\mathrm{m}^{2}$ van Veen grab. Five replicate samples were taken at each of 47 stations (Fig. 1). The large number of samples made the use of a box core for faunal sampling impractical and the use of a van Veen grab also made it possible to compare our results with earlier Russian studies. Sample stations were arrayed along five transects that ran from open water in the south to as far north as ice conditions would allow. The entire contents of a grab were sieved for fauna. The sampling and sample preservation procedures followed international guidelines (ISO 16665), except for the sieve type used (0.75-mm-square-mesh bag, compatible with previous Russian surveys). The different sieve mesh sizes used in NEW and BASICC mean that diversity between the two areas cannot be directly compared.
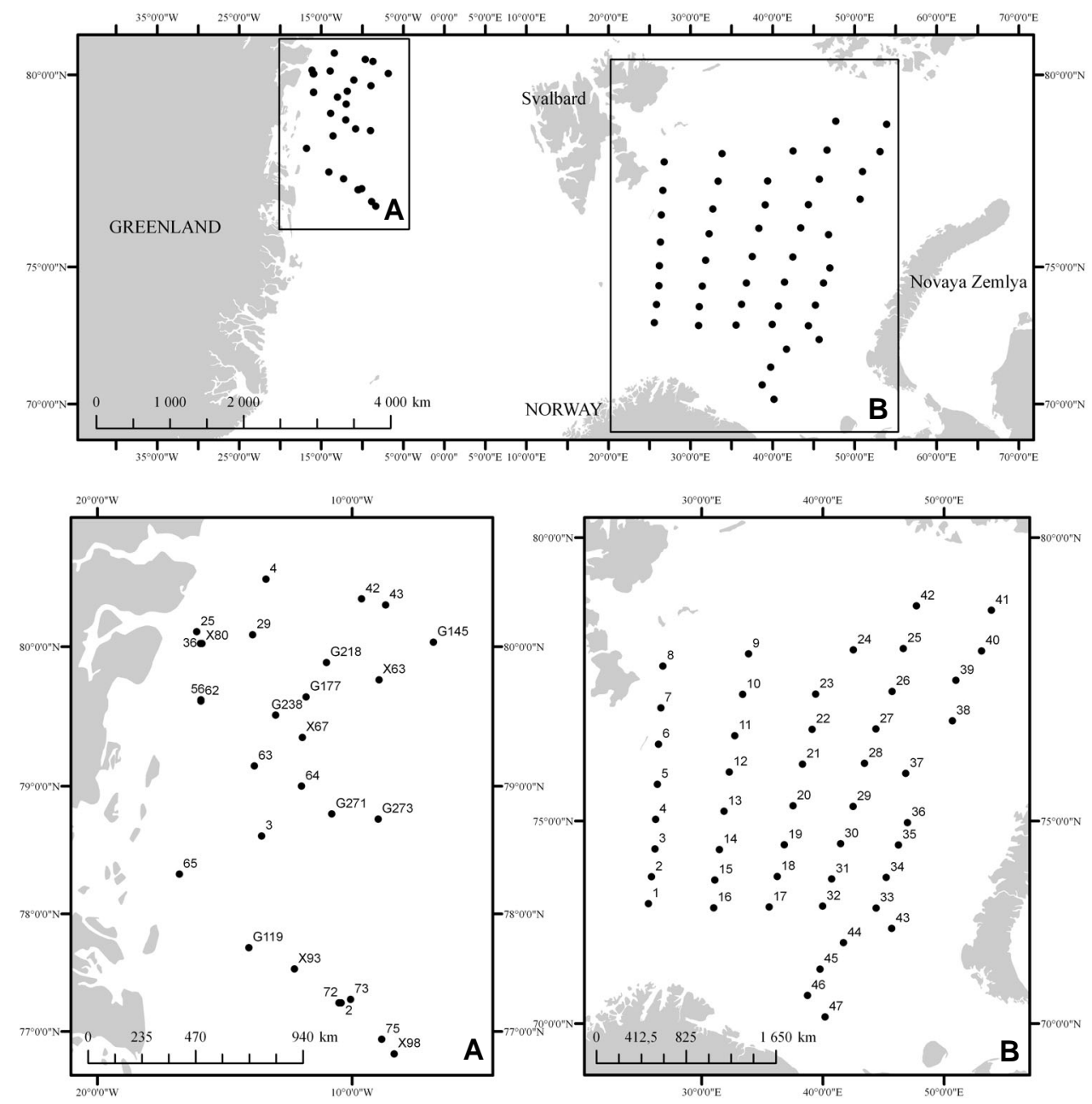

FIGURE 1. Sampling areas and station locations. A, off northeast Greenland; B, in the Barents Sea. 
Sediment parameters. For NEW, benthic chlorophyll $a$ and phaeopigments were determined from one subcore (1.9-cm inside diameter x $2 \mathrm{~cm}$ deep) taken from each box core. Pigments were extracted with $10 \mathrm{~mL}$ of $90 \%$ acetone for $23-25$ hours in the dark at $-20^{\circ} \mathrm{C}$ and concentrations determined fluorometrically using a method based on Holm-Hansen et al. (1965). One subcore was also collected from each box core for total organic carbon analysis. After acidification with $1 \mathrm{~N} \mathrm{HCL}$ to remove calcium carbonate, the sediment was dried, homogenized, and run on a Control Equipment Corporation model 440 elemental analyzer using acetanilide as a standard. One final subcore $(4.0 \mathrm{~cm}$ x $15 \mathrm{~cm}$ deep) was collected for sediment grain size. Samples were processed according to procedures outlines in Folk (1980), including pipette analysis for the silt/clay fraction.

In the BASICC program, we used a $0.25-\mathrm{m}^{2}$ box core to collect undisturbed sediment samples. Sediment for pigments (chlorophyll $a$ and $b$, and their degradation products-phaeopigments) was collected from the top $1 \mathrm{~cm}$ of sediment, which was analyzed by the Norwegian Institute for Water Research (NIVA) using HPLC. Sediment for grain size analysis was also collected from the top $1 \mathrm{~cm}$ of the sediment and analyses carried out by dry sieving for the coarser fraction $>0.063 \mathrm{~mm}$ and using a Sedigraph 5000 unit to analyze the finer fraction. Pigment and grain size analyses were conducted by GeoGruppen Analyse AS, Troms $\varnothing$.

Ice Data. Sea ice data was obtained from the National Snow and Ice Data Center (Cavalieri et al. 2006). This data set is generated from brightness temperature data derived from Nimbus-7 Scanning Multichannel Microwave Radiometer (SMMR) and Defense Meteorological Satellite Program (DMSP) Special Sensor Microwave/Imager (SSM/I) passive microwave data at a grid cell size of 25 x $25 \mathrm{~km}$ (http://nsidc.org/data/nsidc-0051.html). For both NEW and BASICC, the grid cel matching the position for each station was identified, and monthly mean data from these grid cells were extracted from the database. The chosen periods were: for the NEW study area from 1990 to 1993 and for the BASICC area from 2000 to 2003. These periods were chosen to cover four years of ice coverage before sampling and covered the presumed life span of many of the polychaetes. Based on these data, the average ice concentration for the peak productivity season (May-October) was computed for each year and station.

Production. For BASICC we also had an estimate of primary production at each station. Integrated water column production for each of the stations was estimated using the SINMOD coupled physical-biological ecosystem model for the Barents Sea (Slagstad \& McClimans 2005; Wassmann et al. 2006b). The annual production data were extracted from the $4 \times 4 \mathrm{~km}$ pixel corresponding to each station for two years $(2002,2003)$ using realistic climate forcing functions (Ellingsen et al. 2008), and the results were averaged.

Faunal identification. Taxonomic determination was carried out to the lowest feasible taxonomic level, and recorded without reference to Linnean ranks (see the PhyloCode at http:// www.ohiou.edu/phylocode/), as also was done for the BASICC data in Cochrane et al. (2009). Identifications were made by S. Gagaev, Zoological Institute, Russian Academy of Sciences, St. Petersburg (BASICC), and K. Sandøy, Bates College, Lewiston, ME USA (NEW). Within some identified taxa, two or more forms were recognized but not named, due to a combination of deviation from available taxonomic descriptions, uncertain taxonomic status in the available literature, or juvenile or damaged specimens. These are marked (*) in the appended taxon list. The nomenclature used for both data sets was standardized using the World Register of Marine Species (WoRMS; http:/ /www.marinespecies.org/). Although names are used consistently within each study, issues of discrepancies in identifier practices between two independent studies always remain a problem for comparative analyses. Therefore, we minimize direct comparison of taxon richness between the NEW and BASICC data sets and focus mainly on comparing the relative trends within each of the two studies. Further, we make no assumptions of polychaetes as a proxy for macrofaunal diversity (see critique in Bertrand et al., 2006). 
Statistical analysis. Polychaete abundances in sub-cores from each box core were averaged in the NEW study and then box cores treated as replicates and averaged for each station. In BASICC, the data from the five van Veen grabs at each station were pooled prior to statistical analysis. We averaged (pseudoreplicate) subcores in NEW because sample sizes among box cores were different. In BASICC we had the same numbers of grabs at each station, so averaging and pooling would produce the same index values. We ran analyses on single values for each station because we are interested in differences at the station (not grab or core) level, and this is the same scale at which the environmental parameters were measured.

The ice analysis revealed differences in ice cover between the Northern Trough, Southern Trough and Bank stations in NEW, which agreed with previous studies of ice coverage in NEW (Schneider \& Budéus 1995; Minnett et al. 1997), and we used these characterizations in all statistical analysis (see Table 1 for station designations).

For comparisons of the BASICC stations, we separated the stations into three zones (Northern, Southern, and Polar Front). This grouping is based on a combination of several related factors. First, a 10-year average ice concentration (1992-2001) indicates that the zones correspond to approximately $>25 \%,<15 \%$, and $15-25 \%$ ice cover, respectively (Denisenko 2002). Secondly, they are associated with the water masses dominant in the respective zones: Atlantic Water dominating in the south, Arctic Water in the north, and a mix in the frontal area (Cochrane et al. 2009). Finally, the Polar Front is a persistent feature in the southern/central Barents Sea, and the stations we designated as 'front' stations correspond to the average annual position of the front (Loeng 1991, Falk-Peterson et al. 2000). Denisenko (2002) has also used this geographic distribution of sample sites in his investigation of benthic secondary production. We compared parameters from stations among these three regions (see Table 2 for station designations).

Species accumulation curves were generated for each of the different locations (Northern Trough, Southern Trough, Bank) within NEW and North, South and Polar Front within BASICC and for all the stations combined in each study using the EstimateS package (Colwell 1997). We also used Hurlbert's rarefaction (Hurlbert 1971) to compare diversity among regions in both NEW and BASICC. This method calculates the expected number of species in a sample of $n$ individuals. There were insufficient numbers to calculate $\mathrm{ES}_{(\mathrm{n})}$ for individual stations, so we pooled samples among areas in NEW (Southern Trough, Northern Trough, and Bank) and BASICC (North, Sound, Front). These calculations also allow us to compare our polychaete diversity with diversity in other areas of the Arctic.

Shannon-Wiener diversity index $\left(\mathrm{H}^{\prime}\right.$, based on natural $\left.\mathrm{log}\right)$ and Simpson's Reciprocal Index (1/ D) were calculated for polychaete taxa at each station for NEW and BASICC using Biodiversity Pro. Simpson's Reciprocal Index has been shown to be more sensitive than the Shannon-Wiener Index to changes in benthic community structure (Gray 2000). We used linear regressions to explore possible relationships between depth, sediment grain size, and diversity/evenness. We also compared differences in $\mathrm{H}^{\prime}$ and $1 / \mathrm{D}$, depth, mean grain size, organic carbon, pigment concentrations, and ice cover among stations in different geographic areas (NEW) or with different ice cover (BASICC) using ANOVA after testing for homogeneity of variances (Sokal \& Rohlf 1995). When necessary, data were transformed using a log transformation and re-tested. When an ANOVA was significant, we used the post-hoc Bonferonni test to determine differences between means.

We also used a multiple step-wise regression to examine linear relationships between $\mathrm{H}^{\prime}$ and 1/D and environmental variables. Variables were included in the regression only if there was a suggestion from correlation analysis that they may explain a significant portion of the variability in diversity $(\mathrm{p}<0.15)$. 
TABLE 1. Northeast Water Polynya (NEW) station information. Abbreviations: Sta. (station), lat. (N. latitude) long. (W. longitude), location (geographic designation), Depth (water in meters), B-pig. (benthic sediment pigments, chlorophyll $a$ and phaeopigments), Phi (mean grain size), 1/D (Simpson's Reciprocal Index), $\mathrm{H}^{\prime}$ (Shannon-Wiener diversity index). Samples were collected between June and August in 1992 and 1993. ND = no data.

\begin{tabular}{|c|c|c|c|c|c|c|c|c|c|c|}
\hline Sta. & Lat. & Long. & Location & $\begin{array}{l}\text { Depth } \\
\text { (m) }\end{array}$ & $\begin{array}{l}\text { B-Pig. } \\
\mathbf{m g} / \mathbf{m}^{2}\end{array}$ & Ice \% & $\begin{array}{l}\text { TOC } \\
\%\end{array}$ & Phi & 1/D & $\mathbf{H}^{\prime}$ \\
\hline 2 & 77.25 & 10.42 & $\mathrm{~S}$ trough & 470 & 12.22 & 60.2 & ND & 6.954 & 7.00 & 0.845 \\
\hline 65 & 78.32 & 16.78 & $\mathrm{~S}$ trough & 505 & 7.22 & 82.1 & 0.61 & 6.952 & 8.10 & 0.975 \\
\hline 72 & 77.25 & 10.51 & $\mathrm{~S}$ trough & 490 & 10.6 & 60.7 & 0.68 & 6.947 & 5.67 & 0.885 \\
\hline 73 & 77.28 & 10.05 & $\mathrm{~S}$ trough & 355 & 8.92 & 60.7 & 0.95 & 6.576 & 11.34 & 1.233 \\
\hline 75 & 76.93 & 8.83 & $\mathrm{~S}$ trough & 363 & 8.82 & 54.7 & 0.63 & 6.135 & 10.63 & 1.090 \\
\hline X93 & 77.54 & 12.26 & $\mathrm{~S}$ trough & 502 & 1.09 & 65.4 & 0.57 & 6.742 & 8.33 & 0.960 \\
\hline X98 & 76.8 & 8.34 & $\mathrm{~S}$ trough & 348 & 3.89 & 50.1 & 0.9 & 6.334 & 9.39 & 1.055 \\
\hline G119 & 77.72 & 14.05 & $\mathrm{~S}$ trough & 378 & 1.39 & 67.9 & 0.55 & 6.534 & 12.16 & 1.193 \\
\hline G177 & 79.65 & 11.8 & $\mathrm{~S}$ trough & 326 & 6.52 & 64.3 & 0.7 & 6.802 & 4.71 & 0.990 \\
\hline G145 & 80.03 & 6.8 & $\mathrm{~N}$ trough & 310 & 8.74 & 43.4 & ND & ND & 9.84 & 1.116 \\
\hline 4 & 80.45 & 13.38 & $\mathrm{~N}$ trough & 315 & 15.14 & 43.4 & 0.71 & 6.648 & 8.47 & 1.124 \\
\hline 25 & 80.1 & 16.1 & $\mathrm{~N}$ trough & 310 & 14.82 & 51.8 & 0.61 & 5.499 & 18.14 & 1.434 \\
\hline 29 & 80.08 & 13.9 & $\mathrm{~N}$ trough & 180 & 14.11 & 48.5 & 1.45 & 6.102 & 6.54 & 0.924 \\
\hline 36 & 80.02 & 15.95 & $\mathrm{~N}$ trough & 152 & 45.62 & 46.8 & 0.46 & 6.397 & 14.79 & 1.233 \\
\hline 42 & 80.32 & 9.62 & $\mathrm{~N}$ trough & 440 & 10.14 & 56.5 & 0.71 & 6.913 & 5.25 & 1.000 \\
\hline 43 & 80.28 & 8.68 & $\mathrm{~N}$ trough & 316 & 32.63 & 59.3 & 0.97 & 6.852 & 7.35 & 1.125 \\
\hline 56 & 79.63 & 15.93 & $\mathrm{~N}$ trough & 285 & 32.56 & 72.9 & 0.95 & 6.803 & 5.01 & 0.986 \\
\hline 62 & 79.62 & 15.93 & $\mathrm{~N}$ trough & 176 & 11.98 & 68.6 & 0.56 & 6.445 & 7.41 & 1.141 \\
\hline G218 & 79.89 & 11.0 & $\mathrm{~N}$ trough & 320 & 19.47 & 75.0 & ND & 6.195 & 17.81 & 1.420 \\
\hline G238 & 79.52 & 13.0 & $\mathrm{~N}$ trough & 229 & 61.39 & 79.6 & ND & 6.862 & 6.85 & 1.356 \\
\hline G273 & 78.75 & 8.97 & Bank & 169 & 24.07 & 70.8 & 0.59 & 5.076 & 14.29 & 1.318 \\
\hline 3 & 78.62 & 13.55 & Bank & 150 & 11.39 & 69.4 & 0.53 & 5.602 & 18.88 & 0.976 \\
\hline 63 & 79.15 & 13.83 & Bank & 125 & 26.16 & 46.8 & 0.75 & 6.443 & 6.25 & 1.432 \\
\hline 64 & 79 & 11.98 & Bank & 217 & 46.86 & 60.2 & 0.68 & 6.101 & 19.61 & 1.465 \\
\hline X63 & 79.77 & 8.93 & Bank & 201 & 22.55 & 82.1 & ND & 6.316 & 19.62 & 1.248 \\
\hline X67 & 79.36 & 11.95 & Bank & 241 & 10.09 & 60.7 & 0.88 & 6.437 & 13.44 & 1.064 \\
\hline X80 & 80.02 & 15.89 & Bank & 425 & 16.31 & 60.7 & 0.65 & 6.679 & 7.11 & 1.142 \\
\hline G271 & 78.79 & 10.79 & Bank & 355 & ND & 54.7 & ND & 7.065 & 8.54 & 1.047 \\
\hline
\end{tabular}

Finally, we also used Principal Component Analysis (PCA) (Canoco ver. 4.5), a multivariate ordination method, to explore the relationships between diversity $\left(\mathrm{H}^{\prime}\right.$ and $\left.1 / \mathrm{D}\right)$ and environmental variables. Canoco allows environmental data and, in our case, diversity data to be plotted together by treating the diversity measurements as supplemental data that do not affect the ordination. The environmental variables used in the PCA were: ice cover, benthic pigments, TOC, water depth and sediment grain size (phi for NEW and pelite for BASICC), and for BASICC we also included modeled primary production. Diversity is then plotted into the ordination without affecting the weighting of the environmental variables. While some of these parameters are likely correlated, the 
relationships between any two of these parameters are far from perfect. Even the typical depth-grain size relationship does not hold well for the Barents Sea $(r=0.19)$, where many northern areas are deeper and have lower pelite content (Table 2).

TABLE 2. Barents Sea (BASICC) station information. Abbreviations: lat. (N. latitude) long. (E. longitude), loc. (location relative to long-term ice cover, North $>25 \%$ cover, South $<15 \%$ cover, PF $=$ Polar Front, $15-25 \%$ cover), Depth (water in meters), B-pig. (benthic pigments, chlorophyll $a$ and phaeopigments), Ice (percent ice cover JuneSeptember 2001-2003), TOC (total organic carbon), Pelite (percent slit and clay), Prod. (primary production), 1/D (Simpson's reciprocal index), H' (Shannon-Wiener diversity index). Samples were collected in August in 2003.

\begin{tabular}{|c|c|c|c|c|c|c|c|c|c|c|c|}
\hline Sta. & $\begin{array}{l}\text { Lat. } \\
\text { (N) }\end{array}$ & $\begin{array}{l}\text { Long. } \\
\text { (E) }\end{array}$ & Loc. & $\begin{array}{l}\text { Depth } \\
\text { (m) }\end{array}$ & $\begin{array}{l}\text { B-Pig. } \\
\mathbf{m g} / \mathbf{m}^{2}\end{array}$ & $\begin{array}{l}\text { Ice } \\
\%\end{array}$ & $\begin{array}{l}\text { TOC } \\
\%\end{array}$ & $\begin{array}{l}\text { Pelite } \\
\%\end{array}$ & $\begin{array}{l}\text { Prod. } \\
\mathrm{gC} / \mathbf{m}^{2} / \\
\mathrm{yr}\end{array}$ & 1/D & $\mathbf{H}^{\prime}$ \\
\hline 1 & 73.1262 & 25.6272 & South & 425 & 0.18 & 0 & 1.76 & 88.9 & 121.3 & 4.13 & 2.573 \\
\hline 2 & 73.7582 & 25.8763 & South & 459 & 1.08 & 0 & 1.78 & 65.4 & 100.1 & 19.92 & 3.172 \\
\hline 3 & 74.3917 & 26.1683 & $\mathrm{PF}$ & 387 & 0.4 & 0.4 & 1.46 & 42.8 & 95.2 & 21.92 & 3.159 \\
\hline 4 & 75.0338 & 26.2217 & $\mathrm{PF}$ & 218 & 3.63 & 6.3 & 2.39 & 61.6 & 76.6 & 16.85 & 2.36 \\
\hline 5 & 75.7635 & 26.3607 & $\mathrm{PF}$ & 130 & 3.63 & 23.0 & 2.01 & 36.2 & 79.6 & 8.47 & 3.435 \\
\hline 6 & 76.5562 & 26.4648 & North & 79 & 3.74 & 38.3 & 1.78 & 83.7 & 92.3 & 8.28 & 3.512 \\
\hline 7 & 77.2343 & 26.6607 & North & 133 & 1.6 & 47.1 & 1.63 & 91.3 & 79.4 & 13.87 & 3.189 \\
\hline 8 & 77.9773 & 26.8253 & North & 136 & 2.76 & 55.1 & 1.84 & 76.7 & 52.8 & 14.16 & 2.803 \\
\hline 9 & 78.1858 & 33.8855 & North & 164 & 1.51 & 56.9 & 1.25 & 64.3 & 34.3 & 5.48 & 2.68 \\
\hline 10 & 77.4792 & 33.3938 & North & 144 & 0.92 & 49.8 & 1.46 & 40.9 & 43 & 9.22 & 3.085 \\
\hline 11 & 76.7185 & 32.7503 & North & 190 & 0.93 & 34.4 & 0.75 & 32.7 & 50 & 7.09 & 3.122 \\
\hline 12 & 76.0102 & 32.3042 & $\mathrm{PF}$ & 323 & 3.28 & 14.6 & 2.31 & 82.7 & 56.2 & 7.88 & 2.46 \\
\hline 13 & 75.2037 & 31.8597 & $\mathrm{PF}$ & 338 & 1.44 & 3.9 & 2.2 & 88.0 & 59.5 & 13.59 & 2.838 \\
\hline 14 & 74.3772 & 31.4807 & $\mathrm{PF}$ & 260 & 2.12 & 0.02 & 1.77 & 59.3 & 65.8 & 6.85 & 2.983 \\
\hline 15 & 73.6853 & 31.0980 & South & 374 & 0.48 & 0.01 & 1.71 & 82.0 & 68.3 & 6.50 & 2.885 \\
\hline 16 & 73.0262 & 31.0103 & South & 279 & 0.51 & 0.01 & 1.26 & 54.6 & 101.2 & 5.29 & 3.184 \\
\hline 17 & 73.0447 & 35.5818 & South & 224 & 3.17 & 0.1 & 1.75 & 53.8 & 67.8 & 4.65 & 2.86 \\
\hline 18 & 73.7660 & 36.2557 & South & 245 & 4.66 & 0.9 & 1.29 & 61.9 & 65.3 & 8.03 & 2.578 \\
\hline 19 & 74.4817 & 36.8368 & $\mathrm{PF}$ & 224 & 4.16 & 5.3 & 2.00 & 43.3 & 53.5 & 11.07 & 2.273 \\
\hline 20 & 75.3193 & 37.5542 & $\mathrm{PF}$ & 169 & 4.63 & 11.4 & 2.13 & 35.5 & 46.4 & 7.16 & 2.29 \\
\hline 21 & 76.1678 & 38.3477 & $\mathrm{PF}$ & 258 & 1.95 & 20.7 & 1.13 & 36.5 & 36 & 7.99 & 2.748 \\
\hline 22 & 76.8392 & 39.1303 & North & 192 & 2.79 & 36.9 & 1.35 & 79.8 & 28.9 & 7.48 & 2.83 \\
\hline 23 & 77.4857 & 39.4295 & North & 217 & 2.06 & 43.0 & 1.56 & 88.8 & 23 & 9.97 & 2.567 \\
\hline 24 & 78.2508 & 42.5382 & North & 221 & 2.2 & 47.3 & 1.05 & 66.2 & 17.3 & 6.56 & 2.642 \\
\hline 25 & 78.2762 & 46.6610 & North & 244 & 1.18 & 47.2 & 1.09 & 66.9 & 16.2 & 4.51 & 2.624 \\
\hline 26 & 77.5325 & 45.7313 & North & 251 & 2.71 & 36.2 & 1.6 & 79.7 & 17.5 & 3.71 & 2.48 \\
\hline 27 & 76.8443 & 44.3962 & North & 275 & 3.81 & 26.0 & 2.25 & 85.0 & 20.5 & 6.00 & 2.145 \\
\hline 28 & 76.1818 & 43.4648 & $\mathrm{PF}$ & 342 & 2.96 & 16.6 & 2.16 & 71.5 & 25.5 & 7.39 & 2.157 \\
\hline 29 & 75.3045 & 42.5082 & $\mathrm{PF}$ & 267 & 2.72 & 11.5 & 1.39 & 50.4 & 32 & 12.72 & 2.01 \\
\hline 30 & 74.5042 & 41.4867 & $\mathrm{PF}$ & 208 & 2.73 & 8.4 & 1.31 & 53.4 & 39.7 & 8.63 & 2.287 \\
\hline 31 & 73.7060 & 40.7472 & South & 295 & 3.56 & 5.1 & 1.68 & 54.0 & 48 & 9.64 & 2.454 \\
\hline
\end{tabular}

TABLE 2 (continued) 


\begin{tabular}{|c|c|c|c|c|c|c|c|c|c|c|c|}
\hline Sta. & $\begin{array}{l}\text { Lat. } \\
\text { (N) }\end{array}$ & $\begin{array}{l}\text { Long. } \\
\text { (E) }\end{array}$ & Loc. & $\begin{array}{l}\text { Depth } \\
\text { (m) }\end{array}$ & $\begin{array}{l}\text { B-Pig. } \\
\mathrm{mg} / \mathrm{m}^{2}\end{array}$ & $\begin{array}{l}\text { Ice } \\
\%\end{array}$ & $\begin{array}{l}\text { TOC } \\
\%\end{array}$ & $\begin{array}{l}\text { Pelite } \\
\%\end{array}$ & $\begin{array}{l}\text { Prod. } \\
\mathrm{gC} / \mathbf{m}^{2} / \\
\mathrm{yr}\end{array}$ & 1/D & $\mathbf{H}^{\prime}$ \\
\hline 32 & 73.0647 & 39.9983 & South & 324 & 1.95 & 1.8 & 1.57 & 57.4 & 60.6 & 6.03 & 2.929 \\
\hline 33 & 73.0217 & 44.4072 & South & 335 & 2.56 & 0.3 & 1.96 & 58.7 & 48.6 & 3.79 & 2.637 \\
\hline 34 & 73.7415 & 45.2518 & South & 340 & 3.78 & 0.5 & 1.96 & 59.1 & 37.4 & 6.91 & 2.872 \\
\hline 35 & 74.4757 & 46.2527 & $\mathrm{PF}$ & 243 & 4.33 & 3.1 & 0.43 & 17.0 & 31.8 & 5.58 & 2.605 \\
\hline 36 & 74.9650 & 47.0032 & $\mathrm{PF}$ & 243 & 10.15 & 6.2 & 1.52 & 51.0 & 28.1 & 9.06 & 2.112 \\
\hline 37 & 76.9958 & 50.7037 & $\mathrm{PF}$ & 349 & 2.66 & 32.3 & 1.45 & 47.4 & 21.1 & 10.93 & 2.404 \\
\hline 38 & 77.7290 & 51.0025 & North & 225 & 2.11 & 39.5 & 1.69 & 82.2 & 14.7 & 17.72 & 1.879 \\
\hline 39 & 78.2343 & 53.1197 & North & 305 & 1.11 & 49.7 & 1.07 & 61.3 & 14 & 11.03 & 2.666 \\
\hline 40 & 78.8997 & 53.9292 & North & 241 & 1.46 & 51.4 & 1.29 & 69.1 & 11.8 & 6.57 & 2.723 \\
\hline 41 & 78.9700 & 47.7498 & North & 254 & 3.62 & 54.5 & 0.99 & 67.3 & 12.4 & 5.95 & 3.228 \\
\hline 42 & 75.9822 & 46.8593 & North & 268 & 2.54 & 49.7 & 2.18 & 41.5 & 15.7 & 9.48 & 2.862 \\
\hline 43 & 72.5198 & 45.7058 & South & 284 & 3.14 & 15.2 & 1.68 & 52.8 & 49.6 & 6.67 & 2.682 \\
\hline 44 & 72.1622 & 41.7267 & South & 286 & 2.65 & 0.01 & 2.25 & 80.8 & 60.7 & 10.22 & 2.461 \\
\hline 45 & 71.4822 & 39.7998 & South & 365 & 1.86 & 0.1 & 2.75 & 76.8 & 64.9 & 4.13 & 2.746 \\
\hline 46 & 70.7790 & 38.7498 & South & 233 & 0.51 & 0 & 1.2 & 53.7 & 83.7 & 19.92 & 2.74 \\
\hline 47 & 70.1887 & 40.2060 & South & 145 & 2.5 & 0.02 & 0.47 & 17.4 & 94.7 & 21.92 & 2.934 \\
\hline
\end{tabular}

\section{Results}

\section{Northeast Water Polynya (NEW)}

Ice conditions varied among the three regions in NEW. Between 1990 and 1993, Bank stations experienced an average 67.4\% $(\mathrm{SE}=3.5)$ ice cover from May-October. This value was significantly greater (Table 3) than that from either the Northern Trough $(55.8 \%, \mathrm{SE}=2.9)$ or the Southern Trough $(62.9 \%, \mathrm{SE}=3.0)$, which were not significantly different from each other. Though not considered in the ice coverage analysis, ice in the Southern Trough was thicker than ice on the Bank or in the Northern Trough (WGA, pers. obs.). It was not possible to sample very coarse sediment in the shallow areas of the Northeast Water Polynya using the box core; sampling was, therefore, limited to finer sediments in the deeper areas of the central Bank. This limitation had the effect of sampling similar depths and grain size in all areas (Tables 1-2).

Cores in NEW sampled approximately $2 \mathrm{~m}^{2}$ and collected 1797 polychaetes representing 177 taxa (Appendix 1). The species accumulation curve shows no indication of reaching an asymptote (Fig. 2A). Individual species accumulation curves for the three regions indicated that polychaete species richness was slightly higher in the Southern Trough compared to the Bank and Northern Trough (Fig. 2B). The pooled $\mathrm{ES}_{(201)}$ value for the Northern Trough was lower (53.0) than values for either the Bank (64.6) or Southern Trough stations (69.89).

While the species accumulation curves and $\mathrm{ES}_{(201)}$ values suggested differences in richness among the three regions, there was no significant difference in the Shannon-Wiener diversity index, $\mathrm{H}^{\prime}$ (Table 3). The index was slightly lower in the Southern Trough (1.025, SE=0.044), than in the Northern Trough (1.169, SE=0.052) or the Bank (1.212, SE=0.065). There was also no difference in 1/D among areas (Table 3). The index was similar for the Northern Trough (Mean = 9.77, $\mathrm{SE}=1.46$ ) and Southern Trough $(\mathrm{Mean}=8.59, \mathrm{SE}=0.846)$, but higher on the Bank $($ Mean = 13.48, $\mathrm{SE}=1.99)$. 

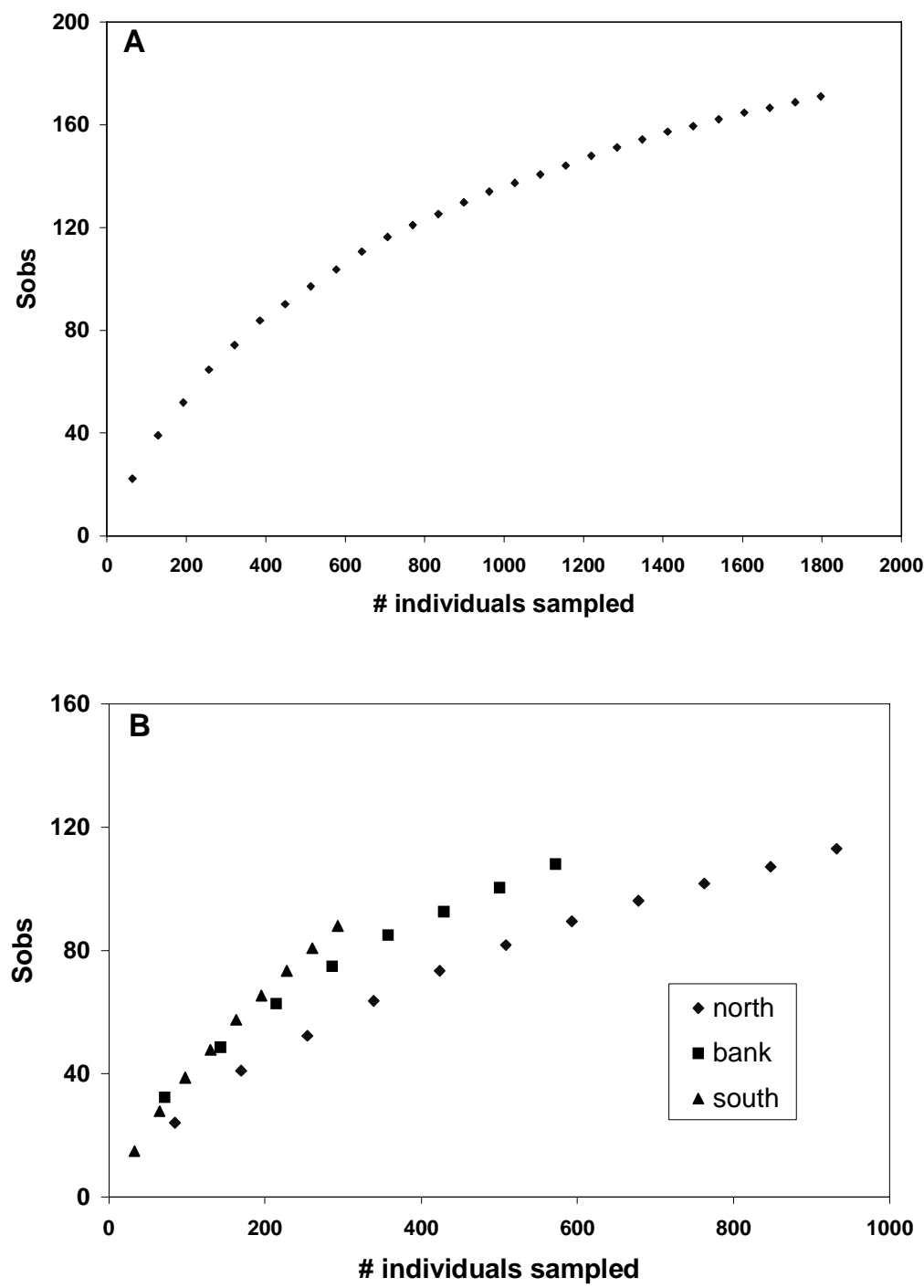

FIGURE 2. A, Species accumulation curve for polychaetes from 28 stations in the North East Water Polynya, East Greenland Shelf; B, species accumulation curves for polychaetes from three regions in the North East Water Polynya: Northern Trough, Bank, and Southern Trough.

There were differences among the three regions in physical and biological conditions. Despite our efforts to sample similar depths in each region, the mean depth of stations in the Southern Trough (415.2 m, SE=24.8) was significantly deeper than stations on the Bank $(235.4 \mathrm{~m}, 36.8)$ or in 
the Northern trough (275.2 m, SE=25.4), which were not significantly different from each other (Table 3). There was also a significant difference in the mean concentration of benthic pigments among the three regions, with the concentration of pigments in the Southern Trough $\left(6.74 \mathrm{mg} / \mathrm{m}^{2}\right.$, $\mathrm{SE}=1.4)$ lower by a factor of four than in the Northern Trough $\left(24.24 \mathrm{mg} / \mathrm{m}^{2}, \mathrm{SE}=5.1\right)$ and Bank (22.49 mg/m², SE=4.7), which were not significantly different from each other (Table 3). Despite the difference in depth between the stations in the Southern Trough and those on the Bank and in the Northern Trough, there were no differences in the mean grain size among these regions (Table 3 ).

TABLE 3. ANOVA tables for (A) NEW (NT = Northern Trough, ST $=$ Southern Trough) and (B) BASICC (South $=$ less than $15 \%$ ice cover over 10 years, $\mathrm{PF}=15-25 \%$ ice cover, North $=$ greater than $25 \%$ cover). Pair-wise comparisons between means were made using the Bonferonni post hoc test when an ANOVA was significant (Bold face; $p<0.05)$ and differences are significant at $\mathrm{p}<0.05$. NS $=$ not significant $(\mathrm{p}>0.05)$.

\begin{tabular}{lclll}
\hline A. & & & & \\
Variable & F-value & df & $\mathbf{p}$-value & Multiple comparisons \\
\hline Ice cover & 3.52 & 2.25 & $\mathbf{p}<\mathbf{0 . 0 4}$ & NT, ST $<$ Bank \\
Depth & 9.79 & 2.25 & $\mathbf{p}<\mathbf{0 . 0 0 0 1}$ & ST $>$ NT, Bank \\
Benthic pigments & 10.77 & 2.24 & $\mathbf{p}<\mathbf{0 . 0 0 0 1}$ & ST $<$ NT, Bank \\
Grain size (phi) & 1.46 & 1.46 & $\mathrm{p}>0.2$ (NS) & NS \\
Organic carbon & 0.34 & 2.19 & $\mathrm{p}>0.7$ (NS) & NS \\
H' diversity & 3.13 & 2.25 & $\mathrm{p}<0.06$ & NS \\
1/D & 2.68 & 2.25 & $\mathrm{p}<0.08$ & NS \\
& & & & \\
\hline B. & & & & \\
Variable & F-value & $\mathbf{d f}$ & $\mathbf{p}$-value & Multiple comparisons \\
\hline Ice cover & 145.6 & 2.44 & $\mathbf{p}<\mathbf{0 . 0 0 1}$ & South $<$ PF $<$ North \\
Depth & 7.88 & 2.44 & $\mathbf{p}<\mathbf{0 . 0 0 0 1}$ & South $>$ North \\
Productivity & 11.31 & 2.44 & $\mathbf{p}<\mathbf{0 . 0 0 1}$ & South $>$ PF, North \\
Benthic pigments & 7.47 & 2.44 & $\mathbf{p}<\mathbf{0 . 0 5}$ & South, North $<$ PF \\
Grain size (pelite) & 3.88 & 2.44 & $\mathbf{p}<\mathbf{0 . 0 3}$ & PF $<$ North \\
Organic carbon & 1.23 & 2.44 & $\mathrm{p}<0.30$ & NS \\
H' diversity & 2.15 & 2.44 & $\mathrm{p}<0.129$ & NS \\
1/D & 3.62 & 2.44 & $\mathbf{p}<\mathbf{0 . 0 4}$ & North $>$ PF \\
\hline
\end{tabular}

For NEW, only mean grain size $(\mathrm{p}<0.001)$ entered the step-wise multiple regression and explained $51 \%$ of the variability in $\mathrm{H}^{\prime}$ indicating that the Shannon index increases with an increase in grain size.

$$
\mathrm{H}^{\prime}=-0.244 \text { (phi) }+2.68
$$

In the second multiple regression, benthic pigments $(\mathrm{p}<0.03)$ along with water depth $(\mathrm{p}<0.003)$ and organic carbon $(\mathrm{p}<0.03)$ together explained $47.6 \%$ of the variability in Simpson's Reciprocal Index (1/D):

$$
1 / \mathrm{D}=-0.03 \text { (depth) }+8.9 \text { (organic carbon) }-0.157 \text { (B-pig.) }+16.26
$$

The first two axes of the PCA explained $62.1 \%$ of the variability in the environmental data (Fig. 
3A). Diversity as measured by Shannon-Wiener $\left(\mathrm{H}^{\prime}\right)$ is strongly related to benthic pigment concentration and was negatively related to water depth and grain size (phi). Interestingly, the PCA indicates that ice cover was not related to benthic pigments or diversity. The results are very similar when Simpson's Index (1/D) is used instead of the Shannon-Wiener index.
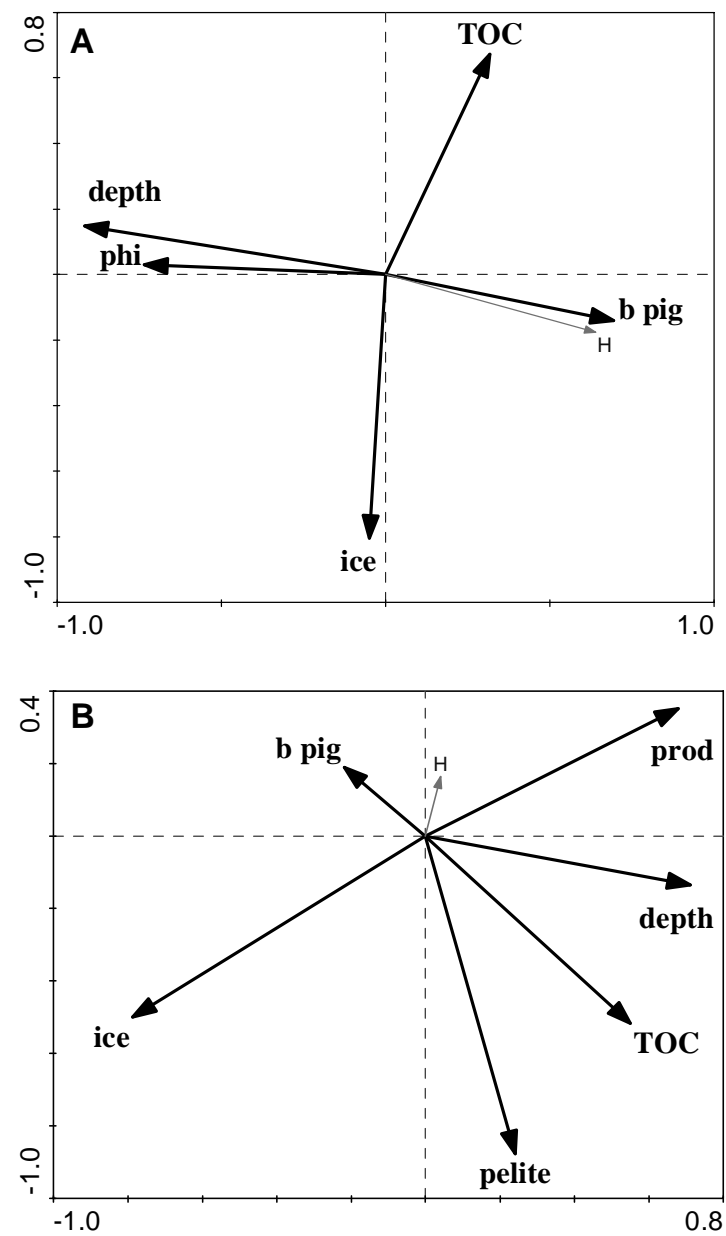

FIGURE 3. Graphical representation of the results of the Principle Components Analysis for (A) NEW and (B) BASICC environmental variables. The Shannon-Wiener diversity index $\left(\mathrm{H}^{\prime}\right)$ was entered as a supplemental variable in each analysis and is indicated by a grey vector. The first two axes explain $62.1 \%$ and $57.6 \%$ of the variability in the data for NEW and BASICC respectively.

\section{BASICC}

May through October ice conditions for 2001-2003 agreed with the longer-term ice data and other parameters used to classify stations in BASICC. Southern stations had a mean ice coverage of $1.6 \%$ $(\mathrm{SE}=1.0)$ for May to October in the four years preceding the study, while Northern stations had an average of $44.9 \%$ ( $\mathrm{SE}=2.1$ ) coverage and Polar Front stations had a mean ice coverage of $10.9 \%$ $(\mathrm{SE}=2.4)$. Mean ice cover was significantly different $(\mathrm{p}<0.001)$ among all areas (Table 3$)$. 
Grab sampling covered approximately $24 \mathrm{~m}^{2}$ at the 47 BASICC stations and collected a total of 36,240 individual polychaetes from 158 taxa (Appendix 1). The species accumulation curve for all BASICC stations showed no indication of reaching an asymptote (Fig. 4A). More polychaete species were collected from the 17 Northern stations under heavier ice cover compared to areas with less ice for a similar number of individuals sampled (Fig. 4B). For Northern stations, 125 species were collected for 6,765 individuals compared to 115 species for 11,746 individuals from Southern stations and 123 species for 17,729 individuals from stations under the Polar Front. The calculation of $\mathrm{ES}_{(201)}$ revealed the greatest richness of polychaetes under the heaviest ice cover in the North $\left(\mathrm{ES}_{(201)}=53.3\right)$ compared to $\mathrm{ES}_{(201)}$ values of 42.4 and 38.9 for Southern and Polar Front regions, respectively.
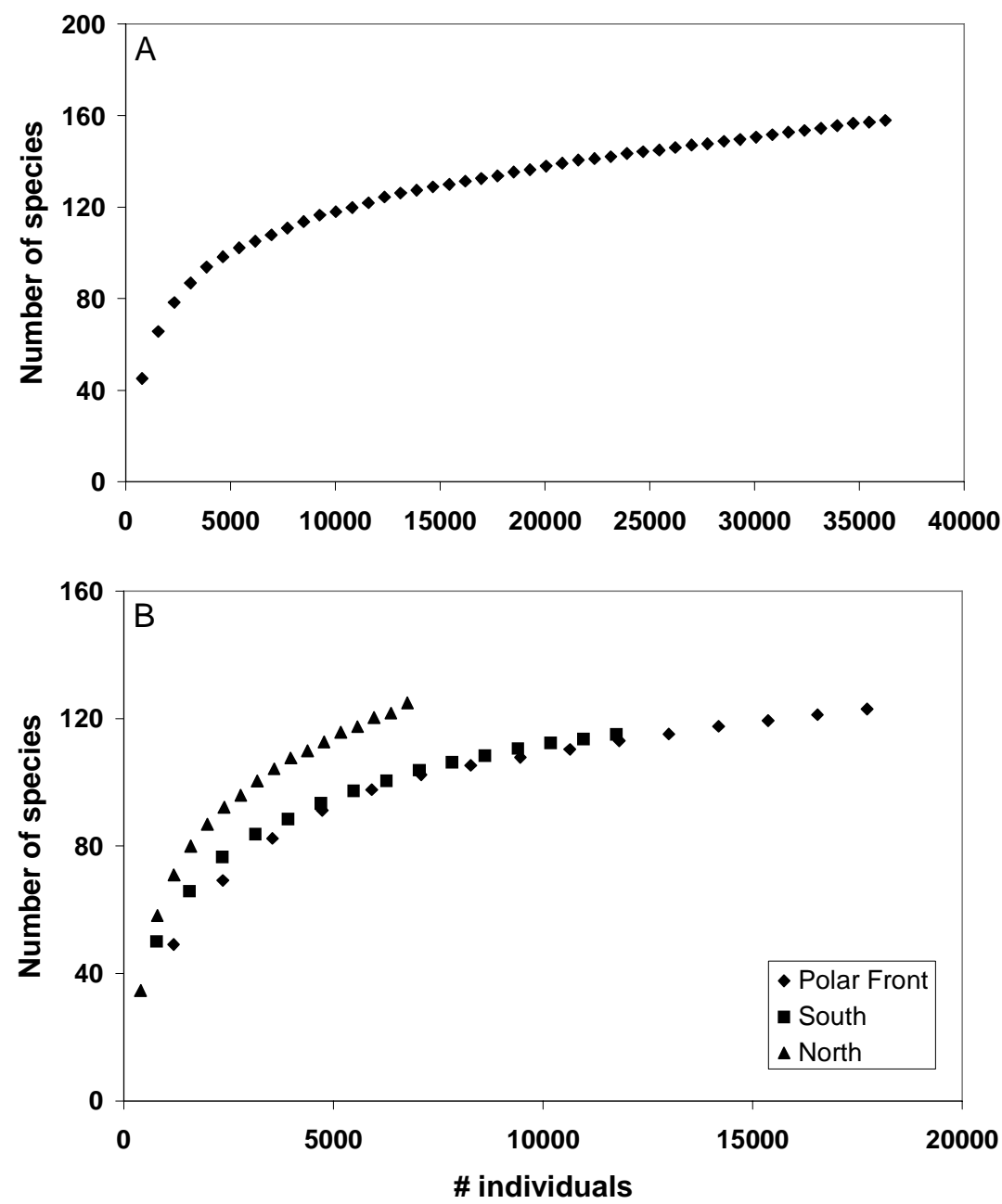

FIGURE 4. A, Species accumulation curve for polychaetes from 47 stations sampled as part of the BASICC project in the Barents Sea; B, species accumulation curves for polychaetes from three regions (North, Polar Front, and South) in the BASICC project area (see Table 2 for designations). 
Even though the species accumulation curves suggested greater species richness in areas with the greatest ice cover, there was no significant difference in $\mathrm{H}^{\prime}$ among areas (Table 3). Mean $\mathrm{H}^{\prime}$ was very similar between Northern $(2.767, \mathrm{SE}=0.097)$, Polar Front (mean $=2.781, \mathrm{SE}=0.058$ ), and Southern regions (mean=2.541, $\mathrm{SE}=0.197$ ). There was, however, a significant difference in 1/D among regions (Table 3). The Northern region with more ice had a significantly higher index (Mean $=11.06, \mathrm{SE}=1.09)$ than the Polar Front region $(\mathrm{Mean}=7.15, \mathrm{SE}=1.09)$ while the index $(\mathrm{Mean}=$ 9.22, $\mathrm{SE}=0.91$ ) in the South was not significantly different from either of the other two regions.

There were differences in the depth of stations $(\mathrm{p}<0.001)$ and the percent fine sediment (pelite) among the regions (Table 3 ). Northern stations were significantly shallower (mean depth $=208.2 \mathrm{~m}$, $\mathrm{SE}=14.7)$ compared to Southern stations $(\mathrm{Mean}=307.5, \mathrm{SE}=20.9)$ while Polar Front stations had a mean depth of $263.9 \mathrm{~m}(\mathrm{SE}=18.5)$ which was not significantly different for the other two areas. Northern stations also had a greater proportion of pelite (fine sediment) (Mean=69.3\%, SE=4.2) than Polar Front stations (Mean=51.8\%, SE=4.6), while fine sediment was not significantly different between these two regions and the Southern stations (Mean=61.2\%, SE=4.4).

Differences in the concentration of benthic pigments among the regions were marginally significant (Table 3). There was no difference in benthic pigment concentration between the Southern and Northern stations (mean=2.17, $\mathrm{SE}=0.36$, and 2.18, $\mathrm{SE}=0.23$, respectively), but these concentrations were less than at the Polar Front stations (mean=3.39, $\mathrm{SE}=0.564$ ). This marginal difference in benthic pigments was not reflected in the amount of total organic carbon among the regions, which was not significantly different and varied over a small range from $1.46 \%$ at stations in the north to $1.71 \%$ at stations under the Polar Front (Tables 2-3).

Productivity among the three regions was significantly different (Table 3). Southern stations from the area had significantly higher mean annual productivity (mean=71.48, $\mathrm{SE}=6.14)$ than stations from the Polar Front (mean=48.80, $\mathrm{SE}=5.73$ ) or the North (mean=31.99, $\mathrm{SE}=5.86$ ).

For BASICC, only productivity and ice cover entered the multiple regression, and explained $48.6 \%$ of the variability with p-values for both predictors significant at 0.001 .

$$
\mathrm{H}^{\prime}=0.019 \text { (prod) }+0.001(\text { ice })+2.18
$$

The results were similar for the multiple regression with $1 / \mathrm{D}$, with $43.4 \%$ of the variability in $1 / \mathrm{D}$ explained:

$$
1 / \mathrm{D}=0.112(\text { prod })+0.149(\text { ice })+5.72
$$

$\mathrm{p}$-values for both variables were less than 0.0001 .

The first two axes of the PCA explained $57.6 \%$ of the variability in the data (Fig. 3B). The Shannon-Wiener diversity index $\left(\mathrm{H}^{\prime}\right)$ was most closely associated with benthic pigments, as in NEW, and with modeled primary productivity. The diversity vector, however, is small, indicating that the first two axes of the ordination based on environmental variables do not explain much of the variation in diversity. As in NEW, there was no relationship between benthic pigments and ice cover, but modeled primary productivity is highly negatively correlated with ice cover. We also included Simpson's Reciprocal Index (1/D) in PCA for each area and the results were very similar to H'.

Appendix 2 shows the 10 numerically dominant and frequently occurring taxa at each of the three locations for the Northeast Water Polynya (NEW) and the Barents Sea (BASICC) data sets. The overall top dominant taxa comprised 15.6-20.2\% of the total individuals present in the NEW area, and 9.9-23.5\% in the BASICC area. At the NEW Northern trough and Bank locations, only four of the numerically most abundant taxa also were among the most frequently occurring (present at $80 \%$ or more of the stations). For the Southern trough, none of the taxa were present at more than $78 \%$ of the stations. 


\section{Discussion}

Polychaete species richness patterns on the continental shelves of the Barents Sea and of northeast Greenland indicated that these two communities were distinct, but may well be structured by similar processes. While neither shelf area came close to reaching asymptotes on their respective species accumulation curves, and total polychaete richness was similar, it took 10 times the area and 20 times the number of individuals sampled to achieve similar taxon richness in BASICC as for NEW. Mechanistically, however, they were remarkably similar in that regions with lower primary productivity (Barents Sea) or proxies of primary productivity (benthic pigments, Northeast Greenland and Barents Sea), and highest ice concentration (both sites) exhibited the greatest taxonomic abundance as indicated by both species accumulation curves and $\mathrm{ES}_{(201)}$.

In support of NEW and the Barents Sea having distinct community compositions, only Maldane sarsi was a numerical dominant at all locations in both datasets. Four taxa were dominant across all the NEW locations: Prionospio cirrifera, M. sarsi, Aricidea quadrilobata, and Eclysippe vanelli. All of these taxa display some extent of vertical particle transport or diffusive mixing behavior (see Pearson 2001). For BASICC, Spiophanes kroeyeri, Galathowenia oculata, Spiochaetopterus typicus, and Heteromastus filiformis were common dominants, all of which all of which are "conveyor-belt" particle transporters. Prionospio cirrifera, which was among the overall dominants at all the NEW locations, was dominant only at the Northern location in BASICC. Conversely, Heteromastus filiformis and Galathowenia oculata, which were dominant at all BASICC locations, were dominant only at the NEW North and Bank locations, respectively. Chaetozone setosa dominated at the NEW North and Bank locations, reminiscent of the BASICC Polar Front location, which was dominated by unidentified species of Chaetozone.

There is striking similarity in species richness on Arctic shelves, although it appears to be a little lower in the Laptev and Beaufort Seas than in other areas (Curtis 1975; Stewart et al. 1985; Grebmeier et al. 1989; Kendall \& Aschan 1993; Kendall 1996; Włodarska-Kowalczuk et al. 1998; Sejr et al. 2000; Sirenko 2001; Steffens et al. 2006; Renaud et al. 2007a). Considering polychaetes alone, of 796 taxa recorded from all the Russian Arctic seas, a total of 341 records were from the Barents Sea, 181 and 174 from the Chukchi Sea and Kara Sea, respectively, whereas only 114 are recorded from the Laptev Sea (Zoological Institute, St. Petersburg Census of Marine Life project; available at www.zin.rulprojects). In fjords, the estimated number of species for 201 individuals ranges from 28 in Svalbard to 52 in Greenland. The range of $\mathrm{ES}_{(201)}$ values in our study also varied by

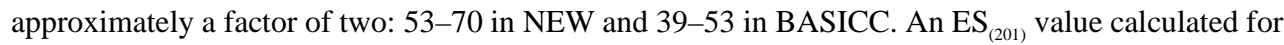
only polychaetes is not directly comparable to one calculated for an entire community, but compared to the few other Arctic studies that have calculated $\mathrm{ES}_{(201)}$, it appears that shelf communities are, perhaps not surprisingly, more diverse than fjord communities.

Diversity indices, as opposed to species richness, incorporate both richness and dominance (or its opposite, evenness). Only Simpson's reciprocal index (1/D) was significantly different among regions and only in the Barents Sea (Table 3). A lower 1/D index indicates greater dominance, in this case where food supply (benthic pigments) is the greatest (Polar Front), and greater evenness where food supply is lowest (North). Primary productivity did not differ significantly between the North and the Polar Front, although it was more than $50 \%$ greater at the Polar Front than in the North. These results are consistent with the general picture of the Polar Front region in the Barents Sea as one of enhanced vertical flux of fresh phytodetritus, but not necessarily higher primary productivity (Wassmann et al. 2006).

The initial picture from the study of richness and diversity indices, then, suggests higher richness in areas of lower food supply. Cochrane et al. (2009) found higher macrofaunal diversity and 
evenness, but lower faunal abundance, in areas with high ice cover and lower annual primary production. Total infaunal abundance and polychaete biomass have also been found to correlate positively with benthic pigments in NEW (Ambrose \& Renaud 1995; Piepenburg et al. 1997). When only the southern and western Barents Sea is considered, diversity patterns are different from the present results: species richness and abundance is positively correlated with benthic chlorophyll in the Barents Sea (Carroll et al. 2008). These results suggests that some taxa, most likely including some polychaete species, respond to food inputs at the population level by increasing in numbers (and perhaps size), and that benthic pigments are a good measure of food supply for what is largely a deposit-feeding polychaete assemblage. Long-lived Arctic benthos, thus, integrate the productivity signal from the pelagic zone, with consequences for richness and diversity patterns.

Multivariate analysis (PCA) from both BASICC and NEW yielded similar results. Both showed no relationship between $\mathrm{H}^{\prime}$ (or 1/D) with ice cover or TOC, and both also indicated a negative relationship between diversity and grain size (higher diversity in coarser sediments). The foodsupply variables primary production and benthic pigments (BASICC) and benthic pigments (NEW) were positively correlated with diversity, though the relationship was weak in BASICC (Fig. 3).

Using benthic pigments as a proxy for production, however, is valid only if the samples are representative of relative differences in annual deposition of food. Since Arctic benthic fauna are capable of rapid consumption of fresh organic material when it reaches the seafloor (McMahon et al. 2006; Renaud et al. 2007b, 2008a), this prerequisite may not be satisfied for all our sampling stations in each shelf area. Unsynchronized peaks in primary production among stations in the region result in our sampling probably missing the annual pulse of material to the benthos at some sites by sampling either too early or too late. While we were able to identify strong patterns in benthic pigments among regions in NEW (4-fold higher in Northern Trough and Bank compared to Southern Trough) and BASICC (a $60 \%$ difference), it is likely that ours is only a rough estimate of relative productivity differences. The PCA from BASICC highlights this, as modeled annual production and one-time measurements of benthic pigments were uncorrelated (Fig. 3B)

Studies of polychaete diversity in the deep sea have found weak evidence for an increase in diversity with productivity in the abyssal Pacific (Glover et al. 2002), a positive correlation between polychaete diversity and meiobenthic abundance, a food proxy, along a shelf to deep sea transect in the Gulf of Mexico (Haedrich et al. 2008), and a parabolic response, highest diversity at intermediate levels of productivity, in the tropical northeast Atlantic (Cosson-Sarradin et al. 1998). Patches of deep-sea sediment enriched with food have been found to support higher densities but lower diversity than unenriched patches (Snelgrove et al. 1992). Levin et al. (2001) suggest that food input, bottom flow, bottom- water oxygen levels, sediment heterogeneity, and ecological disturbance are the five most important factors determining deep-sea benthic diversity. It is likely, therefore, that a suite of biotic and abiotic factors contribute to diversity patterns in soft sediments (Glover et al. 2002).

In shallow water and on shelves there is often only a weak relationship between natural food enrichment and species diversity (see review by Quijón et al. 2008). Surprisingly few studies have experimentally examined the relationship between quality and quantity of phytodetritus and softsediment community structure in shallow water and shelf systems. At $20 \mathrm{~m}$ depth on a boreal shelf, Quijón et al. (2008) found a decrease in diversity in response to experimental addition of phytodetritus, but the response was short lived and seasonally dependent. The rapid utilization of fresh phytodetritus at high latitudes (e.g., Renaud et al. 2008a) may make it hard to examine the relationship between diversity and food on a small scale; larger mesoscale patterns of diversity and food input may provide a clearer picture.

Results from multiple regressions indicate that other environmental variables are important in 
explaining diversity patterns on the two Arctic shelves we studied. In NEW, half of the very low among-station variability in $\mathrm{H}^{\prime}$ was explained by sediment grain size (higher diversity where coarser sediments were found), and this result was supported by the PCA (Fig. 3A). For BASICC, the regressions indicated that diversity was positively correlated with both ice cover and productivity, a finding that contradicts earlier results and the general understanding of the system as having higher productivity under the lowest ice cover regime (Wassmann et al. 2006a). It is important to understand, however, that these regressions are not based on regions, but on individual stations, and that components entering the regression need not correlate with each other. For example, the two different components of $\mathrm{H}^{\prime}$, richness and evenness, may be influenced by separate factors (ice cover and productivity, respectively), even though these factors may be unrelated or negatively related to each other.

The importance of sediment parameters to benthic community structure is well described (Gray 1974, 1997; Pearson \& Rosenberg 1978). The manner in which fauna are impacted by sediment characteristics varies, but factors such as depth, grain size, organic carbon, and bottom currents are often strongly intercorrelated (but see comment above regarding the lack of a strong relationship between depth and \% pelite in the Barents Sea stations). In Arctic waters, metazoan diversity has been shown to be either invariant (Weisshappel \& Svavarsson 1998; Renaud et al. 2006), negatively correlated with depth (Bluhm et al. 2005), peaking at intermediate depths (Kröncke 1994) or reduced in shallow water (Steffens et al. 2006). Most Arctic studies of benthic diversity, however, examined patterns over a much wider depth range than our sampling in NEW and BASICC.

Few hypotheses have been posited to explain Arctic benthic diversity patterns, however. Grebmeier et al. (1989) attributed differences in diversity among areas in the Northern Bering and Chukchi Seas to differences in food supply, sediment heterogeneity, and temperature. They found lower $\mathrm{H}^{\prime}$ diversity under the more productive water masses, but also higher diversity where there was warmer water and more heterogeneous sediment. In studies of Young Sound, East Greenland (Sejr et al. 2000) and Spitzbergen fjords (Włodarska-Kowalczuk et al. 1998; Włodarska-Kowalczuk et al. 2007), patterns of diversity do not appear to be related to any specific environmental factor; though habitat heterogeneity is often invoked as a causative factor it is rarely quantified. Finally, Renaud et al. (2006) suggest that unspecified ecological factors may be driving diversity patterns in macrofaunal communities along a transect from the shelf to the North Pole.

Diversity patterns, where they can be documented, appear to be difficult to explain. Disturbance from iceberg sour has been implicated in determining large-scale patterns in polychaete assemblages in the Antarctic (Kröger \& Rowden 2008), but there is no evidence of physical disturbance from recent iceberg scour in photographs taken at the depth of our stations on the Greenland shelf (Piepenburg \& Schmid 1996; pers. obs.), and the modern icebergs in the Barents Sea are not large enough to scour at the depths we sampled. Instead, our results suggest food supply (a proxy of primary production on these Arctic shelves) and sediment characteristics may be important in determining richness and diversity patterns of polychaetes. Richness is highest at the lowest levels of productivity on both the Greenland shelf and in the Barents Sea. Low resource levels may prevent a few species from becoming very abundant and out-competing rare species, as suggested by increased dominance and reduced 1/D indices in BASICC, and cited increases in abundance under areas of higher pelagic production in NEW. Habitat heterogeneity was not addressed by our study, but patchy distribution of food, combined with small-scale sediment heterogeneity, could also enhance richness. While the mechanism(s) for higher polychaete species richness under greater ice concentration or lower productivity is not clear, it does suggest that a change in polychaete diversity may need to be added to the list of possible changes to the benthos as a consequence of climate change induced changes in ice cover (Renaud et al. 2008b). 


\section{Acknowledgements}

This work was supported by grants from the National Science Foundation (DPP-91-13756) under the Arctic Systems Science Initiative, the Research Council of Norway (contract 152798/730), Norsk Hydro (contract 5341794), Akvaplan-niva and the Zoological Institute, St. Petersburg (ZIN). We thank Ingrid Ellingsen for providing model output for productivity data, Rune Palerud and Chris Emblow for fauna database work, the latter also for creating the station maps. We are grateful for the tireless efforts on our behalf by the crews and offices of the USCG Polar Sea, RV Polarstern, and the RV Ivan Petrov. Laboratory assistance was provided by S. Gagaev, P. Martin, B. Orlando, K. Sandøy, D. Syster, K. Yarborough, and ZIN staff. We would also like to thank our colleagues and collaborators for their insights. In particular, we want to acknowledge the late John Gray for many stimulating discussions about benthic species diversity over coffee. We would also like to thank three anonymous reviewers whose suggestions markedly improved our work. This publication is contribution no.MPS-09008 of MarBEF, within the responsive mode program "ArctEco" (see www.marbef.org).

\section{References}

Ambrose, W.G., Jr. \& Renaud, P.E. (1995) Benthic response to water column productivity: evidence for benthicpelagic coupling in the Northeast Water Polynya. Journal of Geophysical Research, 100 (C3), 4411-4421.

Bertrand, Y., Pleijel, F. \& Rouse, G.W. (2006) Taxonomic surrogacy in biodiversity assessments, and the meaning of Linnaean ranks. Systematics and Biodiversity, 4, 149-159.

Brandt, A. (1997) Abundance, diversity and community patterns of epibenthic- and benthic-boundary layer peracarid crustaceans at $75^{\circ} \mathrm{N}$ off East Greenland. Polar Biology, 17, 159-174.

Bluhm, B.A., MacDonald, I.R., Debenham, C. \& Iken, K. (2005) Macro and megabenthic communities in the high Arctic Canada Basin: initial findings. Polar Biology, 28, 218-231.

Bourke, R.H., Newton , J.L., Paquette, R.G. \& Tunnicliffe, M.D. (1987) Circulation and water masses of the East Greenland shelf. Journal of Geophysical Research, 92, 6729-6740.

Carmack, E.C. \& Wassmann, P. (2006) Food webs and physical-biological coupling on pan-Arctic shelves: Unifying concepts and comprehensive perspectives. Progress in Oceanography, 71, 446-477.

Carmack, E., Barber, D., Christensen, J., Macdonald, R., Rudels, B. \& Sakshaug, E. (2006) Climate variability and physical forcing of the food webs and the carbon budget on panarctic shelves. Progress in Oceanography, 71, 145-181.

Carroll, M. \& Carroll, J. (2003) The Arctic seas. In: Black, K.D. \& Shimmield, G.B. (Eds.), Biogeochemistry of Marine Systems. Blackwell, Oxford, pp.127-156.

Carroll, M.L., Denisenko, S.G., Renaud, P.E. \& Ambrose, W.G. Jr. (2008) Benthic in-fauna of the seasonally icecovered western Barents Sea: Patterns and relationships to physical forcing. Deep-Sea Research II, 55, 23402351.

Cavalieri, D., Parkinson, C., Gloersen, P. \& Zwally H.J. (1996, updated 2006) Sea ice concentrations from Nimbus7 SMMR and DMSP SSM/I passive microwave data. Boulder, Colorado USA: National Snow and Ice Data Center. Digital media.

Clarke, A. \& Harris, C. M. (2003) Polar marine ecosystems: major threats and future change. Environmental Conservation, 30, 1-25.

Cochrane, S.J., Densienko S.G., Renaud P.E., Emblow C.S. \& Ambrose W.G., Jr. (2009) Benthic fauna and productivity regimes in the Barents Sea - ecological implications in a changing Arctic. Sea Research, 61(4), 222-233.

Colwell, R. K., (1997) EstimateS: Statistical estimation of species richness and shared species from samples, 
Version 5. User's Guide and Application. Department of Ecology and Evolutionary Biology, University of Connecticut, Storrs, CT, USA. http://viceroy.eeb.uconn.edu/estimates.

Cosson-Sarradin, N, Sibuet, M., Paterson, G.L.J. \& Vangriesheim, A. (1998) Polychaete diversity at tropical Atlantic deep-sea sites: environmental effect. Marine Ecology Progress Series, 165, 173-185.

Curtis, M. A. (1975) The marine benthos of Arctic and sub-Arctic continental shelves. Polar Record, 17, 595-625.

Declerck, S., Vanderstuken, M., Pals, A., Muylaert, K. \& De Meester, L. (2007) Plankton biodiversity along a gradient of productivity and its mediation by macophytes. Ecology, 88, 2199-2210.

Denisenko, S. G. (2002) Zoobenthos and ice distribution in the arctic seas. Proceedings of the Zoological Institute of the Russian Academy of Sciences, 296, 39-46.

Dobson, S. (1992) Predicting crustacean zooplankton species richness. Limnology and Oceanography 37, 848856.

Dobson, S. I., Arnott, S. E. \& Cottingham, K. L. (2000) The relationship in lake communities between primary productivity and species richness. Ecology, 81, 2662-2679.

Ellingsen, I.H., Delpadado, P., Slagstad, D. \& Loeng, H. (2008) Impact of climatic change on the biological production of the Barents Sea. Climatic Change, 87, 155-175.

Ellingsen, K. E. (2001) Biodiversity of a continental shelf macrobenthos soft-sediment community. Marine Ecology Progress Series, 218, 1-15.

Ellingsen, K. E. (2002) Soft sediment benthic biodiversity on the continental shelf in relation to environmental variability. Marine Ecology Progress Series, 232, 15-27.

Falk-Peterson, S., Hop, H., Budgell, W.P., Hegseth, E.N., Korsnes, R., Løyning, T.B., Ørbæk, J.B., Kawamura, T. \& Shirasawa, K. (2000) Physical and ecological processes in the marginal ice zone of the northern Barents Sea during the summer melt period. Journal of Marine Systems, 27, 131-159.

Fauchald, K. (1977) The polychaete worms. Definitions and keys to the orders, families and genera. Natural History Museum of Los Angeles County, Science Series, 28, 1-188.

Folk, R. L. (1980) Petrology of Sedimentary Rocks. Hemphill, Austin, Texas, USA, 185 pp.

Fredriksen, K. R., Bjelvin, T. A. \& Holm, J. P., (1994) Sediment distribution map Barents Sea. Geogruppen AS Report, 9434.01.01, Tromsø, Norway.

Fukami, T. \& Morin, P. K. J. (2003) Productivity-biodiversity relationships depend on the history of community assembly. Nature, 424, 423-426.

Giangrande, A., Licciano, M. \& Musco, L. (2005) Polychaetes as environmental indicators revisited. Marine Pollution Bulletin, 50, 1153-1162.

Gilliman, L. N. \& Wright, S. D. (2006) The influence of productivity on the species richness of plants: a critical assessment. Ecology, 87, 1234-1243.

Glover, A.G., Smith, C.R., Paterson, G.L.J., Wilson, G.D.F., Hawkins, L. \& Sheader, M. (2002) Polychaete species diversity in the central Pacific abyss: local and regional patterns, and relationships with productivity. Marine Ecology Progress Series, 240, 157-170.

Gradinger, R. (1995) Climate change and biological oceanography of the Arctic Ocean. Philosophical Transactions of the Royal Society of London, 352, 277-286.

Gray, J.S. (1974) Animal-sediment relationships. Oceanography and Marine Biology; An Annual Review, 12, 223261.

Gray, J.S. (1997) Gradients in marine biodiversity. In: Ormond, R.F.G., Gage, J.D. \& Angel, M.V. (Eds.) Marine Biodiversity. Cambridge University Press, Cambridge, pp. 18-34.

Gray, J. S. (2000) The measurement of marine species diversity, with an application to the benthic fauna of the Norwegian continental shelf. Journal of Experimental Marine Biology and Ecology, 250, 23-49.

Grebmeier, J. M., McRoy, C. P. \& Feder, H. M. (1988) Pelagic-benthic coupling on the shelf of the northern Bering Sea and Chukchi Seas. I: Food supply, source, and benthic biomass. Marine Ecology Progress Series, $51,253-268$.

Grebmeier, J.M., Feder, H.M. \& McRoy, C.P. (1989) Pelagic-benthic coupling on the self of the northern Bering and Chukchi Seas. II. Benthic community Structure. Marine Ecology Progress Series, 51, 253-268. 
Haddad, N. M., Haarstad, J. \& Tilman, D. (2000) The effects of long-term nitrogen loading on grassland communities. Oecologia, 124, 73-84.

Haedrich, R.L., Devine, J.A. \& Kendall, V.J. (2008) Predictors of species richness in the deep-benthic fauna of the northern Gulf of Mexico. Deep-Sea Research II, 55, 2650-2656.

Holm-Hansen, O., Lorenzen, C. J., Holmes, R.W. \& Strickland, J. D. (1965) Fluorometric determination of chlorophyll. Journal de Conseil International pour L'exploration de la mer, 30L, 3-15.

Hurlbert, S. H. (1971) The nonconcept of species diversity: a critique and alternate parameters. Ecology, 52, $577-$ 586.

Huston, M. A. (1994) Biological diversity: the coexistence of species on changing landscapes. Cambridge University Press., U.K., 708 pp.

Johannessen, O. M., Shalina, E. V. \& Miles, M. W. (1999) Satellite evidence for an Arctic sea ice cover in transformation. Science, 286, 1937-1939.

Johannessen, O. M., Bengtsson, L. \& Miles, M. W. (2002) Arctic climate change: observed and modeled temperature and sea ice variability. Nansen Environmental and Remote Sensing Center Technical Report, 218, $3-22$.

Kendall, M. A. (1996) Are arctic soft-sediment macrobenthic communities impoverished? Polar Record, 16, 393399.

Kendall, M.A. \& Aschan, M. (1993) Latitudinal gradients in the structure of macrobenthic communities: a comparison of arctic, temperate and tropical sites. Journal of Experimental Marine Biology and Ecology, 172, $157-169$.

Kendall, M.A., Widdicombe, S. \& Weslanwski, J.M. (2003) A multi-scale study of the biodiversity of the benthic infauna of the high-latitude Kongsfjord, Svalbard. Polar Biology, 26, 383-388.

Kondoh, M. (2001) Unifying the relationships of species richness to productivity and disturbance. Proceedings of the Royal Society B: Biological Sciences, 268, 269-271.

Kröncke, I. (1994) Macrobenthos composition, abundance and biomass in the Arctic Ocean along a transect between Svalbard and the Makarov Basin. Polar Biology, 14, 519-529.

Kröger, K. \& Rowden, A.A. (2002) Polychaete assemblages of the northwester Ross Sea shelf: worming out the environmental drivers of Antarctic macrobenthic assemblage composition. Polar Biology, 31, 971-989.

Laxon, S., Peacock, N. \& Smith, D. (2003) High interannual variability in sea ice thickness in the Arctic region. Nature, 425, 947-950.

Levin, L. A. \& Gage, J.D. (1998) Relationships between oxygen, organic matter and the diversity of bathyal macrofauna. Deep Sea Research Part II: Topical Studies in Oceanography, 45, 129-163.

Levin, L. A., Etter, R. J., Rex, M. A., Gooday, A. J., Smith, C. R., Pineda, J., Stuart, C. T., Hessler, R. R. \& Pawson, D. (2001) Environmental influences of regional deep-sea species diversity. Annual Review of Ecology and Systematics, 32, 51-93.

Loeng, H. (1991) Features of the physical oceanographic conditions in the Barents Sea. Polar Research, 10, 5-18.

Mclaren, A. S., Walsh, J. E, Bourke, R. H., Weaver, R. L. \& Wittmann, W. (1992) Variability in sea-ice thickness over the north-pole from 1977 to 1990. Nature, 358, 224-226.

McMahon, K. W., Ambrose, W. G., Jr., Johnson, B. J., Sun, Ming-Yi, Lopez, G. R., Clough, L. M. \& Carroll, M. L. (2006) Benthic community response to ice algae and phytoplankton in Ny Ålesund, Svalbard. Marine Ecology Progress Series, 310, 1-14.

Minnett, P. J., Bignami, F., Böhm, E., Budéus, G., Galbraith, P. S., Gudmandsen, P., Hopkins, T. S., Ngram, G. G., Johnson, M. A., Niebauer, H. J., Famseier, R. O. \& Schneider, W. (1997) A summary of the formation and seasonal progression of the Northeast Water Polynya. Journal of Marine Systems, 10, 79-85.

Mittelbach, G. G., Steiner, C. F., Scheiner, S. M., Gross, K. L., Reynolds, H. L., Waide, R. B., Wilig, M. R., Dodson, S. I. \& Gough, L. (2001) What is the observed relationship between species richness and productivity. Ecology, 82, 2381-2396.

Quijón, P.A., Kelly, M.C. \& Snelgrove, P.V.R. (2008) The role of sinking phytodetritus in structuring shallowwater benthic communities. Journal of Experimental Marine Ecology and Biology, 366, 134-145. 
Parkinson, C. L., Cavalieri, D. J., Gloersen, P., Sawlly, H. J. \& Comsio, J. C. (1999) Arctic sea ice extents, areas, and trends 1978-1996. Journal of Geophysical Research, 104, 20837-20856.

Pearson, T.H. (2001) Functional group ecology in soft-sediment marine benthos: the role of bioturbation. Oceanography and Marine Biology, An Annual Review, 39, 233-267.

Pearson, T.H. \& Rosenberg, R. (1978) Macrobenthic succession in relation to organic enrichment and pollution of the marine environment. Oceanography and Marine Biology, An Annual Review, 16, 229-311.

Piepenburg, D. \& Schmid, M.K. (1996) Distribution, abundance, biomass, and mineralization potential of the epibenthic megafauna of the Northeast Greenland shelf. Marine Biology, 125, 321-332

Piepenburg, D., Ambrose, W. G., Jr., Brandt, A., Renaud, P. E., Ahrens, M. J. \& Jensen, P. (1997) Benthic community patterns reflect water column process in the Northeast Water Polynya (Greenland). Journal of Marine Systems, 10, 467-482.

Renaud, P. E., Ambrose, W. G., Jr., Vanreusel, A. \& Clough, L. M. (2006) Meiofaunal and macrofaunal diversity in the Arctic Ocean. Journal of Experimental Marine Biology and Ecology, 300, 297-306.

Renaud, P.E., Włodarska-Kowalczuk, M., Trannum, H., Holte, B., Węslawski, Cochrane, S., Dahle, S. \& Gulliksen, B. (2007a) Multidecadal stability of benthic community structure in a high-Arctic glacial fjord (van Mijenfjord, Sptizbergen). Polar Biology, 30, 295-305.

Renaud, P. E., Riedel, A., Michel, C., Morata, N., Gosselin, M., Juul-Pedersen, T. \& Chiuchiolo, A. (2007b) Seasonal variation in benthic community oxygen demand: A response to an ice algal bloom in the Beaufort Sea, Canadian Arctic? Journal of Marine Systems, 67, 1-12.

Renaud, P. E., Morata, N., Carroll, M. L., Denisenko, S.G., \& Reigstad, M. (2008a) Pelagic-benthic coupling in the western Barents Sea: processes and time-scales. Deep-Sea Research II, 55, 2372-2380.

Renaud, P. E., Carroll, M. L. \& Ambrose, W. G., Jr. (2008b) Effects of Global Warming on Arctic Sea-Floor Communities and its Consequences for Higher Trophic Levels. In: Duarte, C. M. (Ed.), Impacts of Global Warming on Polar Ecosystesms. Fundacíon BBVA, Bilbao, pp. 139-175.

Rex, M. A., Crame, J. A., Stuart, C. T. \& Clarke, A. (2005) Large-scale biogeographic patterns in marine mollusks: a confluence of history and productivity? Ecology, 86, 2288-2297.

Rosenzweig, M. L. (1995) Species diversity in space and time. Cambridge University Press, Cambridge, UK, 458 pp.

Rosenzweig, M. L. \& Abramsky, Z. (1993) How are diversity and productivity related? In: Ricklefs, R.E. \& Schluter, D. (Eds.), Species Diversity in Ecological Communities: Historical and Geographical Perspectives, University of Chicago Press, pp. 52-65.

Rothrock, D. A, Yu, Y. \& Maykut, G. A. (1999) Thinning of the Arctic sea-ice cover. Geophysical Research Letters, 26, 1-5.

Rysgaard, S., Nielsen, T. \& Hansen, B. W. (1999) Seasonal variation in nutrients, pelagic primary production and grazing in a high-Arctic marine ecosystem, Young Sound, Northeast Greenland. Marine Ecology Progress Series, 179, 13-25.

Schneider, W. \& Budéus, G. (1994) The north east water polynya (Greenland Sea), Polar Biology, 4, 1-9.

Schneider, W. \& \& Budéus, G. (1995) On the generation of the Northeast Water Polynya. Journal of Geophysical Research, 100, 4269-4286.

Schmid, B. (2002) The species richness-productivity controversy. Trends in Ecology \& Evolution, 17, 113-114.

Sejr, M.K., Hense, K.T. \& Rysgaard, S. 2000. Macrobenthic community structure in a high-arctic East Greenland Fjord. Polar Biology, 23, 792-801.

Serreze, M. C., Maslanik, J. A., Scambos, T. A., Fetterer, F., Stroeve, J., Knowles, K., Fowler, C., Drobot, S., Barry, R. G. \& Haran, T. M. (2003) A record minimum arctic sea ice extent and area in 2002. Geophysical Research Letters, 30(3), 1110.

Sirenko, B.I. (Ed.) (2001) List of Species of Free-Living Invertebrates of Eurasian Arctic Seas and Adjacent Deep Waters. Russian Academy of Sciences, St. Petersburg, Russia, 131 pp.

Slagstad, D. \& McClimans, T. A. (2005) Modeling the ecosystem dynamics of the Barents sea including the marginal ice zone: I Physical and chemical oceanography. Journal of Marine Systems, 58, 1-18. 
Snelgrove, P.V.R., Grassle, J.F. \& Petrecca, R. (1996) Experimental evidence for aging food patches as a factor contributing to high deep-sea macrofaunal diversity. Limnology and Oceanography, 41, 605-514.

Sokal, R. R. \& Rohlf, F. J. (1995) Biometry. $3^{\text {rd }}$ edition. W. H. Freeman and Co., San Francisco, USA, 887 pp.

Starmans, A., Gutt, J. \& Arntz, W.E. (2002) Mega-epibenthic communities in Arctic and Antarctic shelf areas. Marine Biology, 135, 269-280.

Steffens, M., Piepenburg, D. \& Schmid, M.K. (2006) Distribution and structure of macrobenthic fauna in the eastern Laptev Sea in relation to environmental factors. Polar Biology, 29, 837-848.

Steiner, C. F. (2003) Keystone predator effects and grazer control of planktonic production. Oikos, 101, 569-577.

Stewart, P.L., Pocklington, P. \& Cuniak. R. (1985) Distribution, abundance and diversity of benthic macroinvertebrates on the Canadian continental shelf and slope of southern Davis Strait and Ungava Bay. Arctic, 38, 281-291.

Svensson, J.R., Lindegarth, M., Siccha, M., Molis, M., Wahl, M. \& Pavia, H. (2007) Maximum species richness at intermediate frequences of disturbance: consistency among levels of productivity. Ecology, 88, 830-838.

Thackeray, S. J. (2007) Crustacean zooplankton species richness and productivity: to what extent do the conclusions depend on the choice of metrics. Oikos, 116, 6714-6728.

Tilman, D. (1982) Resource Competition and Community Structure. Princeton University Press, Princeton, New Jersey, USA, $296 \mathrm{pp}$.

Waide, R. B., Willing, M. R., Steiner, C. F., Mittelbach, G., Gough, L., Dodson, S. I. \& Juday, G. P. (1999) The relationship between productivity and species richness. Annual Review of Ecology and Systematics, 30, 257 300 .

Wassmann, P., Reigstad, M., Haug, T., Rudels, B., Carroll, M. L., Hop, H., Gabrielsen, G.W., Falk-Petersen, S., Denisenko, S. G., Arashkevich, E., Slagstad, D. \& Pavlova, O. (2006a) Food webs and carbon flux in the Barents Sea. Progress in Oceanography, 71, 232-287.

Wassmann, P., Slagstad, D., Wexels Riser, C. \& Reigstad, M. (2006b) Modeling the ecosystem dynamics of the Barents Sea including the marginal ice zone: II Carbon flux and interannual variability. Journal of Marine Systems, 59, 1-24.

Weisshappel, J.B.F. \& Svavarsson, J. (1998) Benthic amphipods (Crustacea: Malacostraca) in Iceland waters: diversity in relation to faunal patterns from shallow to intermediate deep Arctic and North Atlantic Oceans. Marine Biology, 131, 133-143.

Wlodarska-Kowalczuk, M., Weslawski, J. M. \& Kotwicki, L. (1998) Spitzbergen glacial bays-macrofauna. Polar Biology, 20, 66-73.

Wlodarska-Kowalczuk, M. Sicinski, J., Gromisz, S., Kendall, M.A. \& Dahle, S. (2007) Similar soft-bottom polychaete diversity in Arctic and Antarctic marine inlets. Marine Biology, 151, 607-616. 


\section{APPENDIX 1.}

Polychaete taxa collected from the East Greenland Shelf (NEW) and the Barents Sea (BASICC), recorded without reference to Linnean ranks (see Methods). Records of inclusive taxa refer to specimens which could not be identified to a lower level in a consistent manner between the two datasets, for either practical or taxonomic reasons. Taxa within which two or more forms were recognized, but not named are indicated with an *.

\begin{tabular}{|c|c|c|}
\hline Taxon & Author & Location \\
\hline Abyssoninoe hibernica & (McIntosh, 1903) & BASICC \\
\hline Aglaophamus & Kinberg, 1865 & NEW \\
\hline Aglaophamus malmgreni & (Théel, 1879) & BASICC, NEW \\
\hline Amage auricula & Malmgren, 1866 & BASICC, NEW \\
\hline Ampharete & Malmgren, 1866 & BASICC, NEW \\
\hline Ampharete borealis & (Sars, 1856) & BASICC \\
\hline Ampharete finmarchica & (M. Sars, 1864) & BASICC, NEW \\
\hline Ampharete goesi & Malmgren, 1866 & BASICC \\
\hline Ampharetidae* & Malmgren, 1866 & BASICC, NEW \\
\hline Amphicteis gunneri & (M. Sars, 1835) & BASICC, NEW \\
\hline Amphitrite groenlandica & Malmgren, 1866 & BASICC \\
\hline Anobothrus gracilis & (Malmgren, 1866) & BASICC, NEW \\
\hline Anobothrus laubieri & (Desbruyères, 1978) & BASICC, NEW \\
\hline Aphelochaeta marioni & (de Saint Joseph, 1894) & BASICC \\
\hline Apistobranchus tullbergi & (Théel, 1879) & BASICC \\
\hline Apomatus & Philippi, 1844 & NEW \\
\hline Apomatus globifer & Théel, 1878 & BASICC \\
\hline Aricidea abranchiata & Hartman, 1965 & NEW \\
\hline Aricidea hartmani & Strelzov, 1968 & BASICC, NEW \\
\hline Aricidea nolani & Webster \& Benedict, 1887 & BASICC \\
\hline Aricidea quadrilobata & Webster \& Benedict, 1887 & BASICC, NEW \\
\hline Aricidea* & Webster, 1879 & NEW \\
\hline Artacama proboscidea & Malmgren, 1866 & BASICC, NEW \\
\hline Asychis biceps & (M. Sars, 1861) & BASICC \\
\hline Augeneria algida & (Wirén, 1901) & BASICC \\
\hline Axionice maculate & (Dalyell, 1853) & BASICC \\
\hline Axiothella catenata & (Malmgren, 1865) & NEW \\
\hline Bispira crassicornis & (Sars, 1851) & BASICC \\
\hline Brada granulose & Hansen, 1882 & BASICC \\
\hline Brada villosa & (Rathke, 1843) & BASICC \\
\hline Braniella & Hartman, 1965 & NEW \\
\hline Bushiella (Jugaria) quadrangularis & (Stimpson, 1854) & BASICC \\
\hline Bylgides & Chamberlin, 1919 & BASICC \\
\hline Bylgides groenlandicus & (Malmgren, 1867) & BASICC \\
\hline Bylgides promamme & (Malmgren, 1867) & BASICC \\
\hline Capitella capitata & (Fabricius, 1780) & BASICC \\
\hline Capitellidae & Grube, 1862 & NEW \\
\hline Chaetopteridae* & Audouin \& Milne-Edwards, 1833 & NEW \\
\hline
\end{tabular}


APPENDIX 1 (continued)

\begin{tabular}{|c|c|c|}
\hline Taxon & Author & Location \\
\hline Chaetopterus & Cuvier, 1827 & NEW \\
\hline Chaetozone & Malmgren, 1867 & BASICC \\
\hline Chaetozone setosa & Malmgren, 1867 & BASICC, NEW \\
\hline Chitinopoma serrula & (Stimpson, 1854) & BASICC \\
\hline Chone duneri & Malmgren, 1867 & BASICC, NEW \\
\hline Chone infundibuliformis & Krøyer, 1856 & BASICC \\
\hline Chone murmanica & Lukasch, 1910 & BASICC \\
\hline Chone paucibranchiata & (Krøyer, 1856) & NEW \\
\hline Chone perseyi & Zenkevitch, 1925 & BASICC \\
\hline Chone* & Krøyer, 1856 & NEW \\
\hline Circeis armoricana & Saint-Joseph, 1894 & BASICC \\
\hline Circeis spirillum & (Linnaeus, 1758) & BASICC \\
\hline Cirratulidae & Ryckholt, 1851 & NEW \\
\hline Cirratulus & Lamarck, 1801 & BASICC, NEW \\
\hline Cirratulus cirratus & (O.F. Müller, 1776) & NEW \\
\hline Cirrophorus branchiatus & Ehlers, 1908 & BASICC \\
\hline Cirrophorus* & Ehlers, 1908 & NEW \\
\hline Clavodorum & Hartman \& Fauchald, 1971 & NEW \\
\hline Clymaldane & Mesnil \& Fauvel, 1939 & NEW \\
\hline Clymenura polaris & (Théel, 1879) & BASICC \\
\hline Cossura longocirrata & Webster \& Benedict, 1887 & BASICC, NEW \\
\hline Diplocirrus & Haase, 1915 & NEW \\
\hline Diplocirrus glaucus & (Malmgren, 1867) & BASICC \\
\hline Diplocirrus longisetosus & (Marenzeller, 1890) & BASICC \\
\hline Dipolydora coeca & (Oersted, 1843) & BASICC \\
\hline Dipolydora quadrilobata & (Jacobi, 1883) & BASICC \\
\hline Dorvilleidae & Chamberlin, 1919 & NEW \\
\hline Enipo torelli & (Malmgren, 1866) & BASICC \\
\hline Ephesiella macrocirris & Hartman \& Fauchald, 1971 & NEW \\
\hline Erinaceusyllis erinaceus & (Claparède, 1863) & NEW \\
\hline Eteone & Savigny, 1818 & NEW \\
\hline Eteone flava & (Fabricius, 1780) & BASICC, NEW \\
\hline Eteone longa & (Fabricius, 1780) & BASICC, NEW \\
\hline Eteone spetsbergensis & Malmgren, 1865 & BASICC \\
\hline Euchone & Malmgren, 1866 & NEW \\
\hline Euchone analis & (Kröyer, 1865) & BASICC, NEW \\
\hline Euchone papillosa & (Sars, 1851) & BASICC, NEW \\
\hline Eulalia viridis & (Johnston, 1829) & BASICC \\
\hline Eunoe nodosa & (M. Sars, 1861) & BASICC \\
\hline Eusyllis blomstrandi & Malmgren, 1867 & BASICC \\
\hline Exogone (Exogone) naidina & Örsted, 1845 & BASICC \\
\hline Exogoninae & Langerhans, 1879 & NEW \\
\hline
\end{tabular}

.......continued 
APPENDIX 1 (continued)

\begin{tabular}{|c|c|c|}
\hline Taxon & Author & Location \\
\hline Flabelligera affinis & M. Sars, 1829 & BASICC \\
\hline Flabelligeridae & Saint-Joseph, 1894 & NEW \\
\hline Galathowenia oculata & (Zachs, 1922) & BASICC \\
\hline Gattyana cirrhosa & (Pallas, 1766) & BASICC \\
\hline Glycera capitata & Örsted, 1843 & BASICC \\
\hline Glyphanostomum pallescens & (Theel, 1879) & BASICC, NEW \\
\hline Grubianella klugei & $\begin{array}{l}\text { (Pergament, Chlebovitch, } 1964 \text { in } \\
\text { Chlebovitch, 1964) }\end{array}$ & BASICC \\
\hline Haploscoloplos & Monro, 1933 & NEW \\
\hline Harmothoe & Kinberg, 1856 & BASICC \\
\hline Harmothoe aspera & (Hansen, 1878) & BASICC \\
\hline Harmothoe imbricata & (Linnaeus, 1767) & BASICC \\
\hline Harmothoe impar & (Johnston, 1839) & BASICC \\
\hline Harmothoe rarispina & (M. Sars, 1861) & BASICC \\
\hline Hesionidae & Sars, 1862 & NEW \\
\hline Heteromastus filiformis & (Claparède, 1864) & NEW \\
\hline Heteromastus filiformis & (Claparède, 1864) & BASICC \\
\hline Jasmineira elegans & Saint-Joseph, 1894 & NEW \\
\hline Jasmineira schaudinni & Augener, 1912 & NEW \\
\hline Lanassa nordenskioeldi & Malmgren, 1866 & BASICC \\
\hline Lanassa venusta & (Malm, 1874) & BASICC \\
\hline Laonice & Malmgren, 1867 & NEW \\
\hline Laonice cirrata & (M. Sars, 1851) & BASICC \\
\hline Laphania boecki & Malmgren, 1866 & BASICC, NEW \\
\hline Leaena & Malmgren, 1866 & NEW \\
\hline Leaena ebranchiata & (M. Sars, 1865) & BASICC \\
\hline Levinsenia gracilis & (Tauber, 1879) & BASICC \\
\hline Lumbriclymene minor & Arwidsson, 1906 & BASICC \\
\hline Lumbrineridae* & Malmgren, 1867 & NEW \\
\hline Lumbrineris fragilis & (O.F. Müller, 1766) & BASICC, NEW \\
\hline Lumbrineris impatiens & Claparède, 1868 & NEW \\
\hline Lumbrineris magnidentata & Winsnes, 1981 & NEW \\
\hline Lumbrineris scopa & Fauchald, 1974 & NEW \\
\hline Lumbrineris* & Blainville, 1828 & NEW \\
\hline Lysilla loveni & Malmgren, 1866 & BASICC \\
\hline Lysippe labiata & Malmgren, 1866 & BASICC, NEW \\
\hline Macrochaeta & Grube, 1850 & BASICC, NEW \\
\hline Maldane arctica & Detinova, 1985 & BASICC \\
\hline Maldane sarsi & Malmgren, 1865 & BASICC, NEW \\
\hline Maldanidae* & Malmgren, 1867 & BASICC, NEW \\
\hline Marenzelleria arctia & (Chamberlin, 1920) & BASICC \\
\hline Marenzelleria wireni & Augener, 1913 & BASICC \\
\hline
\end{tabular}


APPENDIX 1 (continued)

\begin{tabular}{|c|c|c|}
\hline Taxon & Author & Location \\
\hline Mediomastus & Webster, 1879 & NEW \\
\hline Mediomastus fragilis & Rasmussen, 1973 & NEW \\
\hline Melinna cristata & (M. Sars, 1851) & BASICC, NEW \\
\hline Melinna elisabethae & McIntosh, 1918 & BASICC \\
\hline Melinnopsis & McIntosh, 1885 & NEW \\
\hline Melinnopsis annenkovae & (Ushakov, 1952) & NEW \\
\hline Melinnopsis arctica & (Annenkova, 1931) & NEW \\
\hline Micronephthys minuta & (Théel, 1879) & BASICC \\
\hline Myriochele & Malmgren, 1867 & NEW \\
\hline Myriochele heeri & Malmgren, 1867 & BASICC, NEW \\
\hline Myriochele oculata & Zachs, 1922 & NEW \\
\hline Mystides & Théel, 1879 & BASICC \\
\hline Mystides borealis & Théel, 1879 & BASICC \\
\hline Neopolynoe paradoxa & (Storm, 1888) & BASICC \\
\hline Nephtyidae & Grube, 1850 & NEW \\
\hline Nephtys & Cuvier, 1817 & BASICC \\
\hline Nephtys ciliata & (Müller, 1776) & BASICC, NEW \\
\hline Nephtys paradoxa & Malm, 1874 & BASICC \\
\hline Nephtys pente & Rainer, 1984 & BASICC \\
\hline Nereididae & Johnston, 1865 & NEW \\
\hline Nereimyra & Blainville, 1828 & BASICC, NEW \\
\hline Nereis pelagica & Linnaeus, 1758 & BASICC \\
\hline Nereis zonata & Malmgren, 1867 & BASICC \\
\hline Nicolea zostericola & Örsted, 1844 & BASICC \\
\hline Nicomache & Malmgren, 1865 & NEW \\
\hline Nicomache (Loxochona) quadrispinata & Arwidsson, 1906 & BASICC \\
\hline Nicomache (Loxochona) trispinata & Arwidsson, 1906 & NEW \\
\hline Nicomache lumbricalis & (Fabricius, 1780) & BASICC \\
\hline Nicomachinae & Arwidsson, 1907 & NEW \\
\hline Nothria conchylega & (Sars, 1835) & NEW \\
\hline Nothria hyperborea & (Hansen, 1878) & BASICC \\
\hline Notomastus & Sars, 1850 & NEW \\
\hline Notomastus latericeus & Sars, 1851 & BASICC \\
\hline Notoproctus oculatus & Arwidsson, 1906 & BASICC, NEW \\
\hline Onuphidae* & Kinberg, 1865 & NEW \\
\hline Ophelina acuminata & Örsted, 1843 & BASICC \\
\hline Ophelina cylindricaudata & (Hansen, 1878) & BASICC, NEW \\
\hline Orbiniidae & Hartman, 1942 & NEW \\
\hline Owenia fusiformis & Delle Chiaje, 1844 & BASICC \\
\hline Oweniidae & Rioja, 1917 & NEW \\
\hline Paradexiospira (Spirorbides) vitrea & (Fabricius, 1780) & BASICC \\
\hline Paramphinome jeffreysii & (McIntosh, 1868) & BASICC \\
\hline
\end{tabular}


APPENDIX 1 (continued)

\begin{tabular}{|c|c|c|}
\hline Taxon & Author & Location \\
\hline Paramphitrite birulai & (Ssolowiew, 1899) & BASICC \\
\hline Paranaitis wahlbergi & (Malmgren, 1865) & BASICC \\
\hline Paraninoe minuta & (Théel, 1879) & BASICC \\
\hline Paraonella nordica & Strelzov, 1968 & BASICC \\
\hline Paraonidae & Cerruti, 1909 & NEW \\
\hline Paraonis & Cerruti, 1909 & NEW \\
\hline Pectinaria (Cistenides) hyperborea & (Malmgren, 1866) & BASICC \\
\hline Pectinariidae & Quatrefages, 1866 & NEW \\
\hline Petaloproctus tenuis & (Théel, 1879) & BASICC \\
\hline Pherusa arctica & Støp-Bowitz, 1948 & BASICC \\
\hline Pherusa plumosa & (Müller, 1776) & BASICC \\
\hline Pholoe assimilis & Örsted, 1845 & BASICC \\
\hline Pholoe minuta & (Fabricius, 1780) & NEW \\
\hline Pholoe* & Johnston, 1839 & NEW \\
\hline Phyllodoce & Savigny, 1818 & BASICC \\
\hline Phyllodoce (Anaitides) groenlandica & Oersted, 1842 & BASICC \\
\hline Phyllodocidae & Williams, 1851 & NEW \\
\hline Pionosyllis compacta & Malmgren, 1867 & BASICC \\
\hline Polycirrus & Grube, 1850 & NEW \\
\hline Polycirrus arcticus & Sars, 1865 & BASICC, NEW \\
\hline Polycirrus fedorovi & Jirkov \& Leontovich in Jirkov, 2001 & BASICC \\
\hline Polycirrus medusa & Grube, 1850 & BASICC, NEW \\
\hline Polycirrus norvegicus & Wollebaek, 1912 & NEW \\
\hline Polydora* & Bosc, 1802 & NEW \\
\hline Polynoidae* & Kinberg, 1856 & NEW \\
\hline Polyphysia crassa & (Örsted, 1843) & BASICC \\
\hline Praxillella gracilis & (M. Sars, 1861) & BASICC \\
\hline Praxillella praetermissa & (Malmgren, 1865) & BASICC \\
\hline Praxillura longissima & Arwidsson, 1906 & BASICC, NEW \\
\hline Prionospio cirrifera & Wirén, 1883 & BASICC, NEW \\
\hline Prionospio* & Malmgren, 1867 & NEW \\
\hline Proclea graffi & (Langerhans, 1880) & BASICC, NEW \\
\hline Proclea malmgreni & (Ssolowiew, 1899) & NEW \\
\hline Protodorvillea kefersteini & (McIntosh, 1869) & BASICC \\
\hline Pseudopolydora antennata & (Claparède, 1869) & BASICC \\
\hline Pseudopotamilla reniformis & (Müller, 1771) & BASICC \\
\hline Pseudoscalibregma parvum & (Hansen, 1878) & BASICC \\
\hline Pterolysippe vanelli & (Fauvel, 1936) sensu Eliason, 1955, emend & NEW \\
\hline Pygospio elegans & Claparède, 1863 & BASICC, NEW \\
\hline Rhodine & Malmgren, 1865 & NEW \\
\hline Rhodine gracilior & Tauber, 1879 & BASICC \\
\hline Sabellidae & (Malmgren, 1867) & NEW \\
\hline
\end{tabular}

......continued 
APPENDIX 1 (continued)

\begin{tabular}{|c|c|c|}
\hline Taxon & Author & Location \\
\hline Samythella neglecta & Wollebaek, 1912 & NEW \\
\hline Scalibregma inflatum & Rathke, 1843 & BASICC, NEW \\
\hline Scalibregmatidae & Malmgren, 1867 & NEW \\
\hline Schistomeringos & Jumars, 1974 & NEW \\
\hline Scolelepis korsuni & Sikorski, 1994 & BASICC \\
\hline Scolelepis matsugae & Sikorski, 1994 & BASICC \\
\hline Scoloplos (Scoloplos) armiger & (Müller, 1776) & BASICC \\
\hline Scoloplos acutus & (Verrill, 1873) & BASICC \\
\hline Serpulidae & Rafinesque, 1815 & NEW \\
\hline Sosanopsis wireni & Hessle, 1917 & BASICC, NEW \\
\hline Sphaerodoridium fauchaldi & Hartmann-Schröder, 1993 & BASICC \\
\hline Sphaerodoropsis & Hartman \& Fauchald, 1971 & NEW \\
\hline Sphaerodoropsis minuta & (Webster \& Benedict, 1887) & BASICC, NEW \\
\hline Sphaerodoropsis philippi & (Fauvel, 1911) & BASICC \\
\hline Sphaerodorum gracilis & (Rathke, 1843) & BASICC \\
\hline Spio arctica & (Söderström, 1920) & BASICC \\
\hline Spio armata & (Thulin, 1957) & BASICC \\
\hline Spiochaetopterus typicus & M. Sars, 1856 & BASICC, NEW \\
\hline Spionidae & G.O. Sars, 1872 & NEW \\
\hline Spiophanes kroeyeri & Grube, 1860 & BASICC, NEW \\
\hline Spirorbidae & Pillai, 1970 & NEW \\
\hline Syllidae* & Grube, 1850 & BASICC \\
\hline Syllides & Örsted, 1845 & BASICC \\
\hline Syllides longocirratus & (Örsted, 1845) & NEW \\
\hline Syllis armillaris & (O.F. Müller, 1776) & BASICC \\
\hline Syllis cornuta & Rathke, 1843 & NEW \\
\hline Syllis* & Lamarck, 1818 & NEW \\
\hline Terebellidae & Malmgren, 1865 & NEW \\
\hline Terebellides stroemi & Sars, 1835 & BASICC, NEW \\
\hline Terebellides williamsae & Jirkov, 1989 & BASICC \\
\hline Tharyx* & Webster \& Benedict, 1887 & BASICC, NEW \\
\hline Thelepus cincinnatus & (Fabricius, 1780) & NEW \\
\hline Trichobranchus glacialis & Malmgren, 1866 & BASICC \\
\hline
\end{tabular}




\section{APPENDIX 2.}

List of the 10 numerically dominant taxa recorded from the East Greenland Shelf (NEW) and the Barents Sea (BASICC), recorded without reference to Linnean ranks (see Methods). Abundances expressed as \% of total polychaete individuals at the stations. Frequency expressed as $\%$ of stations within the location containing the taxa (bold type indicates taxa with $>80 \%$ frequency of occurrence).

\begin{tabular}{|c|c|c|c|c|c|c|c|}
\hline \multicolumn{4}{|c|}{ NEW } & \multicolumn{4}{|c|}{ BASICC } \\
\hline North Trough & Taxon & Abund. & Freq. & North & Taxon & Abund. & Freq. \\
\hline Spionidae & Prionospio cirrifera & 20.2 & 100 & Spionidae & Spiophanes kroeyeri & 9.9 & 71 \\
\hline Maldanidae & Maldane sarsi & 17.1 & 82 & Oweniidae & Myriochele heeri & 8.2 & 82 \\
\hline Paraonidae & Aricidea quadrilobata & 7.5 & 36 & Spionidae & Prionospio cirrifera & 7.4 & 88 \\
\hline Ampharetidae & Eclysippe vanelli & 6.3 & 91 & Oweniidae & Galathowenia oculata & 5.0 & 76 \\
\hline Maldanidae & Maldanidae & 5.5 & 73 & Chaetopteridae & Spiochaetopterus typicus & 4.6 & 82 \\
\hline Cirratulidae & Tharyx & 4.2 & 64 & Capitellidae & Heteromastus filiformis & 4.3 & 82 \\
\hline Cirratulidae & Chaetozone setosa & 3.8 & 73 & Sabellidae & Chone murmanica & 3.9 & 35 \\
\hline Capitellidae & Heteromastus filiformis & 1.8 & 55 & Cirratulidae & Aphelochaeta marioni & 3.9 & 88 \\
\hline Onuphidae & Onuphis conchylega & 1.6 & 18 & Lumbrineridae & Scoletoma fragilis & 3.9 & 71 \\
\hline Pholoidae & Pholoe & 1.5 & 55 & Maldanidae & Maldane sarsi & 2.9 & 47 \\
\hline Bank & Taxon & Abund. & Freq. & Front & Taxon & Abund. & Freq. \\
\hline Spionidae & Prionospio cirrifera & 15.6 & 100 & Oweniidae & Galathowenia oculata & 21.9 & 93 \\
\hline Paraonidae & Aricidea quadrilobata & 7.2 & 88 & Chaetopteridae & Spiochaetopterus typicus & 21.3 & 100 \\
\hline Cirratulidae & Tharyx & 6.8 & 50 & Capitellidae & Heteromastus filiformis & 9.4 & 100 \\
\hline Cirratulidae & Chaetozone setosa & 6.5 & 63 & Lumbrineridae & Paraninoe minuta & 6.7 & 100 \\
\hline Ampharetidae & Eclysippe vanelli & 6.1 & 100 & Maldanidae & Maldane sarsi & 5.0 & 100 \\
\hline Maldanidae & Maldanidae indet. & 5.6 & 100 & Spionidae & Spiophanes kroeyeri & 4.4 & 80 \\
\hline Maldanidae & Maldane sarsi & 3.5 & 75 & Cirratulidae & Chaetozone & 3.1 & 87 \\
\hline Onuphidae & Onuphis conchylega & 2.6 & 63 & Orbiniidae & Scoloplos acutus & 2.5 & 100 \\
\hline Maldanidae & Praxillura longissima & 2.6 & 63 & Pholoidae & Pholoe assimilis & 1.2 & 87 \\
\hline Oweniidae & Galathowenia oculata & 2.3 & 63 & Nephtyidae & Aglaophamus malmgreni & 1.1 & 100 \\
\hline \multicolumn{8}{|l|}{ Southern } \\
\hline Trough & Taxon & Abund. & Freq. & South & Taxon & Abund. & Freq. \\
\hline Paraonidae & Aricidea quadrilobata & 19.5 & 78 & Chaetopteridae & Spiochaetopterus typicus & 23.5 & 100 \\
\hline Ampharetidae & Eclysippe vanelli & 8.5 & 56 & Oweniidae & Galathowenia oculata & 12.4 & 100 \\
\hline Spionidae & Prionospio cirrifera & 5.5 & 44 & Maldanidae & Maldane sarsi & 5.5 & 100 \\
\hline Cirratulidae & Tharyx & 5.1 & 44 & Spionidae & Spiophanes kroeyeri & 5.2 & 87 \\
\hline Maldanidae & Maldanidae indet. & 4.8 & 11 & Capitellidae & Heteromastus filiformis & 4.8 & 100 \\
\hline Syllidae & Typosyllis & 3.1 & 22 & Lumbrineridae & Paraninoe minuta & 4.0 & 87 \\
\hline Maldanidae & Maldane sarsi & 2.7 & 44 & Amphinomidae & Paramphinome jeffreysii & 2.8 & 93 \\
\hline Ampharetidae & Ampharetidae & 2.7 & 33 & Cirratulidae & Aphelochaeta marioni & 2.5 & 87 \\
\hline Lumbrineridae & Abyssoninoe scopa & 2.7 & 22 & Sabellidae & Chone murmanica & 2.5 & 87 \\
\hline Syllidae & Ehlersia cornuta & 2.0 & 22 & Maldanidae & Maldane arctica & 2.3 & 60 \\
\hline
\end{tabular}


